\title{
Bioavailable DOC: reactive nutrient ratios control heterotrophic nutrient assimilation-An experimental proof of the macronutrient-access hypothesis
}

\author{
Daniel Graeber (D) Y Youngdoung Tenzin - Marc Stutter • Gabriele Weigelhofer • \\ Tom Shatwell • Wolf von Tümpling • Jörg Tittel • Alexander Wachholz • \\ Dietrich Borchardt
}

Received: 26 October 2020/Accepted: 8 May 2021 / Published online: 8 June 2021

(C) The Author(s) 2021

\begin{abstract}
We investigate the "macronutrient-access hypothesis", which states that the balance between stoichiometric macronutrient demand and accessible macronutrients controls nutrient assimilation by aquatic heterotrophs. Within this hypothesis, we consider bioavailable dissolved organic carbon (bDOC), reactive nitrogen $(\mathrm{N})$ and reactive phosphorus $(\mathrm{P})$ to be the macronutrients accessible to heterotrophic assimilation. Here, reactive $\mathrm{N}$ and $\mathrm{P}$ are the sums of dissolved inorganic $\mathrm{N}$ (nitrate-N, nitrite-N, ammonium-N), soluble-reactive P (SRP),
\end{abstract}

Responsible Editor: J.M. Melack.

Supplementary Information The online version contains supplementary material available at https://doi.org/10.1007/ s10533-021-00809-4.

D. Graeber $(\bowtie) \cdot$ Y. Tenzin · A. Wachholz .

D. Borchardt

Aquatic Ecosystem Analysis and Management,

Helmholtz-Centre for Environmental Research - UFZ,

Brückstr. 3a, 39114 Magdeburg, Germany

e-mail: daniel.graeber@ufz.de

\section{Stutter}

Environmental and Biochemical Sciences, The James

Hutton Institute, Craigibuckler, Aberdeen AB158QH, UK

G. Weigelhofer

Institute of Hydrobiology and Aquatic Ecosystem

Management, University of Natural Resource and Life

Sciences, Vienna, Austria and bioavailable dissolved organic $\mathrm{N}(\mathrm{bDON})$ and $\mathrm{P}$ (bDOP). Previous data from various freshwaters suggests this hypothesis, yet clear experimental support is missing. We assessed this hypothesis in a proofof-concept experiment for waters from four small agricultural streams. We used seven different bDOC:reactive $\mathrm{N}$ and bDOC:reactive $\mathrm{P}$ ratios, induced by seven levels of alder leaf leachate addition. With these treatments and a stream-water specific bacterial inoculum, we conducted a 3-day experiment with three independent replicates per combination of stream water, treatment, and sampling occasion. Here, we extracted dissolved organic matter (DOM) fluorophores by measuring excitation-emission matrices with subsequent parallel factor decomposition (EEMPARAFAC). We assessed the true bioavailability of DOC, DON, and the DOM fluorophores as the

G. Weigelhofer

WasserCluster Lunz, 3293 Lunz am See, Austria

T. Shatwell $\cdot$ J. Tittel

Lake Research, Helmholtz-Centre for Environmental

Research - UFZ, Brückstr. 3a, 39114 Magdeburg,

Germany

W. von Tümpling

River Ecology, Helmholtz-Centre for Environmental

Research - UFZ, Brückstr. 3a, 39114 Magdeburg, Germany 
concentration difference between the beginning and end of each experiment. Subsequently, we calculated the bDOC and bDON concentrations based on the bioavailable EEM-PARAFAC fluorophores, and compared the calculated bDOC and bDON concentrations to their true bioavailability. Due to very low DOP concentrations, the DOP determination uncertainty was high, and we assumed DOP to be a negligible part of the reactive P. For bDOC and bDON, the true bioavailability measurements agreed with the same fractions calculated indirectly from bioavailable EEM-PARAFAC fluorophores (bDOC $\mathrm{r}^{2}=0.96$, $\mathrm{p}<0.001 ;$ bDON $\left.\mathrm{r}^{2}=0.77, \mathrm{p}<0.001\right)$. Hence we could predict bDOC and bDON concentrations based on the EEM-PARAFAC fluorophores. The ratios of bDOC:reactive $\mathrm{N}$ (sum of bDON and DIN) and bDOC:reactive $\mathrm{P}$ (equal to SRP) exerted a strong, predictable stoichiometric control on reactive $\mathrm{N}$ and $\mathrm{P}$ uptake $\left(\mathrm{R}^{2}=0.80\right.$ and 0.83$)$. To define zones of $\mathrm{C}: \mathrm{N}: \mathrm{P}$ (co-)limitation of heterotrophic assimilation, we used a novel ternary-plot approach combining our data with literature data on $\mathrm{C}: \mathrm{N}: \mathrm{P}$ ranges of bacterial biomass. Here, we found a zone of maximum reactive $\mathrm{N}$ uptake $(\mathrm{C}: \mathrm{N}: \mathrm{P}$ approx. $>114:<9: 1)$, reactive $\mathrm{P}$ uptake $(\mathrm{C}: \mathrm{N}: \mathrm{P}$ approx. $>170: 21:<1)$ and reactive $\mathrm{N}$ and $\mathrm{P}$ co-limitation of nutrient uptake (C:N:P approx. $>$ 204:14:1). The "macronutrient-access hypothesis" links ecological stoichiometry and biogeochemistry, and may be of importance for nutrient uptake in many freshwater ecosystems. However, this experiment is only a starting point and this hypothesis needs to be corroborated by further experiments for more sites, by in-situ studies, and with different DOC sources.

Keywords Ecological stoichiometry · Dissolved organic nitrogen $\cdot$ PARAFAC $\cdot$ Dissolved inorganic nitrogen $\cdot$ Phosphate $\cdot$ Ternary plots

\section{Introduction}

The growing intensity of arable land use and farming as well as population growth and urbanization expose aquatic ecosystems to chronic overloading of phosphorus (P) and nitrogen (N) with a plethora of deleterious effects (Kronvang et al. 2005; Conley et al. 2009; Canfield et al. 2010; Weigelhofer et al. 2013; Weigelhofer 2017). The concentrations of reactive $\mathrm{N}$ and $\mathrm{P}$, mainly in the forms of nitrate and soluble reactive phosphorus (SRP), increase globally in streams and rivers. This nutrient overloading could be linked to low ratios of DOC to $\mathrm{N}$ or $\mathrm{P}$, which are far from the "optimum" demand of heterotrophic microbial organisms, limiting $\mathrm{N}$ and $\mathrm{P}$ processing due to insufficient DOC availability (Stutter et al. 2018).

The link between DOC, N, and P concentrations and heterotrophic assimilation is likely controlled by the balance of macronutrient ratios $(\mathrm{C}: \mathrm{N}: \mathrm{P})$ of consumers and their food source, which in turn affects nutrient cycling. Bacteria are the major group controlling microbial heterotrophic macronutrient assimilation. Single bacterial strains can be homeostatic, hence are unable to adapt their cell C:nutrient ratios to their food source, while heterostatic strains are able to adapt their cell C:nutrient ratios, as shown for C:P and various bacterial strains (Scott et al. 2012; Godwin and Cotner 2015). However, even a bacterial community completely consisting of homeostatic strains may adapt to the composition of the food source, as strains with macronutrient ratios close to the one of the food source may increasingly dominate the bacterial community (Danger et al. 2008). Both heterostatic strains and community adaptation may result in a wide range of $\mathrm{C}: \mathrm{N}: \mathrm{P}$ ratios in which nutrient uptake is potentially co-limited by DOC, N, and P. However, it has been pointed out that bacterial community macronutrient ratios can only shift in a range physiologically possible for the bacteria (Danger et al. 2008). Below or above specific food $\mathrm{C}: \mathrm{N}: \mathrm{P}$ ratios, bacterial communities should not be able to adapt anymore, resulting in clear $\mathrm{C}$ or nutrient limitation of the bacterial heterotrophic assimilation.

Large-scale empirical studies linked DOC:nitrate$\mathrm{N}$ ratios to nitrate- $\mathrm{N}$ concentrations and gross uptake, where low DOC:nitrate-N ratios coincided with low nitrate- $\mathrm{N}$ gross uptake (Rodríguez-Cardona et al. 2016; Wymore et al. 2016) and high nitrate-N concentrations (Taylor and Townsend 2010; Helton et al. 2015). Denitrification likely plays a minor role in this stoichiometric effect since earlier studies predicted and empirically found denitrification rates to peak at a molar DOC:nitrate-N ratio of 1 , with no further increase at higher DOC:nitrate-N ratios (Fig. 1) (Taylor and Townsend 2010; Johnson et al. 2012; Hansen et al. 2016). In contrast, heterotrophic assimilation into microbial biomass seems to be the responsible process for the link between DOC:nitrate- 


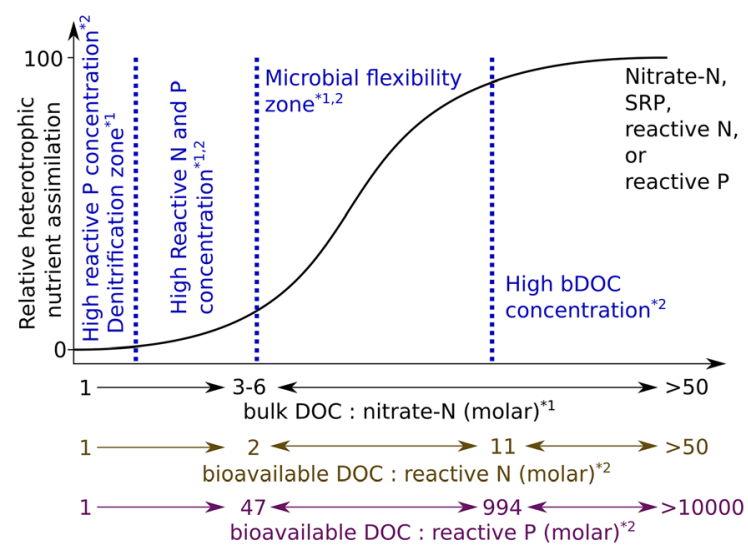

Fig. 1 Conceptual graph depicting the original conceptual model by Taylor and Townsend (2010), linking bulk DOC:nitrate- $\mathrm{N}$ ratios and nitrate heterotrophic assimilation (black gradient, $\left.*^{1}\right)$. We added the idea of including macronutrient accessibility by Stutter et al. (2018), which hypothesized that the balance between microbial stoichiometric demand for macronutrients the availability of accessible nutrients, defined as bioavailable bDOC:reactive $\mathrm{N}$ ratios (yellow-green gradient, $*^{2}$ ) and bDOC:reactive $\mathrm{P}$ ratios (cyan gradient, $*^{2}$ ) in the water control heterotrophic $\mathrm{N}$ and $\mathrm{P}$ assimilation. This macronutrientaccess hypothesis includes a narrow zone at which the DOC:nitrate-N ratio approaches the ideal stoichiometry of denitrification (molar DOC:nitrate- $\mathrm{N}$ ratio $=1$ ) where reactive $\mathrm{P}$ is not assimilated but denitrification can remove reactive $\mathrm{N}$ in the form of nitrate. Above the microbial $\mathrm{C}: \mathrm{N}$ and $\mathrm{C}: \mathrm{P}$, the microbial flexibility zone follows, at which microbial heterotrophs can react flexibly to DOC and/or nutrient additions. Finally above certain $\mathrm{C}: \mathrm{N}$ or $\mathrm{C}: \mathrm{P}$, reactive $\mathrm{N}$ and/or reactive $\mathrm{P}$ assimilation is limited by nutrient availability

$\mathrm{N}$ ratios and nitrate- $\mathrm{N}$ uptake, as heterotrophs should assimilate more $\mathrm{N}$ into biomass when more DOC is available (Fig. 1) (Taylor and Townsend 2010; Stutter et al. 2018). It has been recently shown that the stoichiometric availability of DOC can stimulate stream benthic biofilm (Stutter et al. 2020b) and hyporheic sediment $\mathrm{N}$ and $\mathrm{P}$ assimilation (Stutter et al. 2020a), shifting nutrient losses from inorganic $N$ and $P$ to dissolved organic N (DON) and P (DOP) (Stutter et al. 2020a). Here, we believe that DOC:SRP ratios should have a similar effect on SRP ratios, as has been shown primarily for DOC:nitrate-N ratios and nitrate uptake.

Clear predictions of microbial heterotrophic $\mathrm{N}$ assimilation may not always be derived when solely looking at DOC:nitrate-N ratios, as other dissolved $\mathrm{N}$ fractions may also be important $\mathrm{N}$ sources for heterotrophs. Soares et al. (2017) have shown for boreal freshwaters that bulk DOC:dissolved $\mathrm{N}$ and bulk DOC:dissolved $\mathrm{P}$ ratios are 13-fold higher than the ratios of actually bioavailable DOC:bioavailable dissolved $\mathrm{N}$ and $\mathrm{P}$ to which microbial heterotrophs react with growth. The authors proposed that bulk C:N and $\mathrm{C}: \mathrm{P}$ can give a completely wrong impression of the stoichiometric limitations of heterotrophic nutrient availability and that $\mathrm{C}: \mathrm{N}$ and $\mathrm{C}: \mathrm{P}$ of the bioavailable fractions should be the better predictor. This may also be true in a global perspective, as has been proposed by Stutter et al. (2018) in a meta-analysis (Fig. 1). Here, it has been suggested that reactive macronutrients-those stimulating heterotrophic assimilationinclude all forms of dissolved inorganic nitrogen (DIN, consisting of nitrate, nitrite, ammonium) and SRP, but also bioavailable forms of DOC, dissolved organic nitrogen (DON) and dissolved organic phosphorus (DOP). Thus, we propose the macronutrientaccess hypothesis, which states that microbial nutrient accessibility modifies aquatic heterotrophic nutrient assimilation, more specifically that it is controlled by the balance between bioavailable DOC:reactive macronutrient supply and the microbial stoichiometric macronutrient demand. Hence, by including all bioavailable fractions of DOC, dissolved $\mathrm{N}$ and $\mathrm{P}$, one should be better able to predict stoichiometric constraints of heterotrophic assimilatory nutrient uptake than only by investigating DOC:nitrate ratios or DOC:SRP ratios.

To assess the bioavailable DOC:reactive nutrient ratios, the reactive portion of the dissolved macronutrients needs to be measured. The simplest approach to this are bioavailability experiments with a bacterial inoculum which equals a few percent of the sample volume (e.g. Kaushal and Lewis 2005; Fellman et al. 2010). Reductions in the concentrations of DOC and organic nutrients over time are then used to infer their microbial bioavailability. Such experimentally derived bioavailability of DOC has been closely linked to the occurence of specific fluorophores determined by parallel-factor decomposition of excitation-emission matrices (EEM-PARAFAC) (e.g., Fellman et al. 2010; Kamjunke et al. 2020). Here, EEM-PARAFAC allows for a simple yet fast and practical assessment of DOM composition (Pucher et al. 2019), and may not only be useful to predict DOC bioavailability, but also DON and DOP bioavailability. With EEM-PARAFAC, we may be able to assess the concentration of both bioavailable DOC and 
bioavailable DON and DOP, and the contribution of DON and DOP to reactive, dissolved $\mathrm{N}$ and $\mathrm{P}$.

One major challenge in ecological stoichiometry is to simultaneously assess the effect of stoichiometric imbalances between the $\mathrm{C}: \mathrm{N}: \mathrm{P}$ of food-sources, organisms, and the ecological functions exerted by the organisms. This is also true if one wants to assess stoichiometric effects of $\mathrm{C}: \mathrm{N}: \mathrm{P}$ on heterotrophic nutrient assimilation. In such cases, C:N, C:P, and $\mathrm{N}: \mathrm{P}$ ratios are usually displayed independently, which makes it harder to find co-limitations of the three macronutrients. Ternary plots have been proposed to overcome this issue (Smith et al. 2017; Jarvie et al. 2018). Here, the authors normalized the $\mathrm{C}: \mathrm{N}: \mathrm{P}$ ratios of the target samples (e.g. water samples) to the Redfield ratio to assess stoichiometric limitations resulting in eutrophication. In such a ternary plot, a sample with the Redfield ratio (106C:16N:1P) would be in the center, and samples with specific nutrient depletion or co-depletion relative to this ratio should be situated in specific areas of the plot outside this center (Jarvie et al. 2018). Similar plots could be used to recognize zones of heterotrophic nutrient limitation and to link this to measurements of reactive $\mathrm{N}$ and $\mathrm{P}$ uptake. However, using the Redfield ratio for heterotrophic microbial consumers is less meaningful than using ratios specific for bacteria. To normalize the $\mathrm{C}: \mathrm{N}: \mathrm{P}$ ratios of bacteria, we propose to use data from large-scale investigations of bacterial $\mathrm{C}: \mathrm{N}: \mathrm{P}$ under non-limiting conditions, such as Godwin and Cotner (2018) who found a median of 68C:14N:1P for 137 isolates of planktonic lake bacteria.

So far, the link between DOC and reactive nutrient uptake via stoichiometry is based on empirical evidence and a few experiments, combined with stoichiometric reasoning, requiring experimental testing with a factorial design at a large range of $\mathrm{C}: \mathrm{N}: \mathrm{P}$ ratios. To assess the macronutrient-access hypothesis, we designed a short-term laboratory experiment with different DOC:reactive N:reactive $\mathrm{P}$ ratios using a natural, terrestrial DOC source (Alder leaf leachate). Here, we measured concentrations and bioavailability of inorganic and organic dissolved nutrients, bulk DOC, and assessed DOM fluorophores via EEMPARAFAC. We used water and bacterial inocula from four different streams to assess whether the link between bioavailable C:N:P ratios and reactive nutrient uptake is stream independent. We displayed the $\mathrm{C}: \mathrm{N}: \mathrm{P}$ limitations of reactive $\mathrm{N}$ and $\mathrm{P}$ gross-uptake in ternary plots normalized by the median ratio from Godwin and Cotner (2018) to assess whether we would find specific zones of single or co-limitation of this uptake. Our experiment is a proof-of-concept and focuses on short-term gross-uptake effects. Hence, we cannot make statements about long-term net-effects on aquatic ecosystems. Nevertheless, our relatively robust and straightforward experiment may inspire further research into advancing the macronutrientaccess hypothesis.

For our experiment, we hypothesized that:

1. The DOC:nitrate-N ratio will affect heterotrophic, assimilatory uptake in the manner proposed by monitoring studies (Fig. 1). Furthermore, the relationship proposed for DOC:nitrate-N and nitrate-N uptake is also true for DOC:SRP and SRP uptake, albeit within a different range of DOC:SRP due to different microbial C:N and C:P demand.

2. Bioavailable DOC, DON, and DOP measurements and EEM-PARAFAC can be used to develop bioavailable DOC:reactive N (DIN + bioavailable DON) and bioavailable DOC:reactive $\mathrm{P}$ (SRP + bioavailable DOP) ratios for meaningful stoichiometric constraints of heterotrophic microbial assimilation within the macronutrient-access hypothesis. These constraints better represent the stoichiometric constraints of heterotrophic $\mathrm{N}$ and $\mathrm{P}$ assimilation than those calculated from inorganic nutrients (DIN, SRP) and bulk DOC.

3. The macronutrient ratio of bioavailable DOC, reactive $\mathrm{N}$, and reactive $\mathrm{P}$ is decisive for heterotrophic, microbial nutrient assimilation. Hence, we predict a stream-site independent, heterotrophic assimilation of reactive $\mathrm{N}$ and $\mathrm{P}$ largely driven by bDOC:reactive $\mathrm{N}$ :reactive $\mathrm{P}$, and linked to specific zones in ternary plots normalized by the Godwin-Cotner ratio (GCR) of $68 \mathrm{C}: 14 \mathrm{~N}: 1 \mathrm{P}$.

\section{Methods}

Sample sites

In our study, we used water samples from four small streams in the catchment of the Bode River in Central Germany, which is part of the TERENO 
environmental observatory network (Wollschläger et al. 2017). Water samples were taken from the 1 st order tributaries Getel, Sauerbach, Asse, and Ströbecker Fließ, with surface hydrological catchment areas of $6.8,2.0,30.2$, and $17.4 \mathrm{~km}^{2}$, respectively. The catchments of the sampled streams were mainly or partially used for arable farming and urban land use. Arable land covered 85.3, 28.0, 87.9, and 88.9\% of the catchment area, and urban land covered 14.6, 9.8, 5.0, and $5.7 \%$ of the stream site catchments for Getel, Sauerbach, Asse, and Ströbecker Fließ, respectively. We extracted the data from the 2018 Corine land cover map, and the digital elevation model of the shuttle radar topographic mission was used to determine the hydrological catchment area in QGIS, version 3.12.3.

\section{Experiment preparation}

We used a DOC solution produced from freshly fallen Alder leaves (Alnus glutinosa (L.) Gaert.). The leaves were rinsed, dried at $60{ }^{\circ} \mathrm{C}$ and leached for three days in ultrapure water (Milli-Q synthesis A10) in the dark at $4{ }^{\circ} \mathrm{C}$. The leachate was filtered first through a precombusted $\left(500{ }^{\circ} \mathrm{C}, 4 \mathrm{~h}\right)$ glass-fiber filter (Whatman $\mathrm{GF} / \mathrm{A}$ ) and then through a $0.2 \mu \mathrm{m}$ pore size filter (Nalgene SFCA, surfactant-free cellulose acetate). Aliquots were stored frozen $\left(-22{ }^{\circ} \mathrm{C}\right.$ ) (Attermeyer et al. 2015).

For each stream site, we sampled ten liters of stream water for the incubation and one liter of stream water for the bacterial inoculum into acid-washed polyethylene containers. We took samples on 27th July 2018 from Getel (gt) and Sauerbach (sb) and on 13th August 2018 from Asse (as) and Ströbecker Fließ (sf). Water samples were stored at $4{ }^{\circ} \mathrm{C}$ and transported to the laboratory for immediate filtration. The bacterial inoculum samples were filtered with GF/C filters (Whatman) with an approximate cutoff of $1.4 \mu \mathrm{m}$ to remove algae and zooplankton as much as possible, without losing bacteria. These filters were rinsed beforehand with $1 \mathrm{~L}$ of deionized water (Milli-Q ${ }^{\circledR}$, Merck, Darmstadt, Germany) to remove potential residual production-related DOC from the filters (Yoro et al. 1999). The water samples for incubation were filtered through pre-rinsed $0.22 \mu \mathrm{m}$ polycarbonate membrane filters (Millipak 60 Gamma Gold Capsule, Durapore membrane, Merck) to remove any bacteria. We took an aliquot from each stream water sample for DOC and nutrient analysis, and started the experiments within two days of the sampling.

\section{Experiment setup}

We first prepared a stock DOC solution extracted from Alder leaves with concentrations of DOC, nitrate-N, nitrite-N, ammonium-N, DON, SRP, and DOP of $3780 \mathrm{mg} \quad \mathrm{L}^{-1},<0.42 \mathrm{mg} \quad \mathrm{L}^{-1},<0.06 \mathrm{mg} \quad \mathrm{L}^{-1}$, $11.0 \mathrm{mg} \mathrm{L}^{-1}, 4.3 \mathrm{mg} \mathrm{L}^{-1}, 20.2 \mathrm{mg} \mathrm{L}^{-1}$, and $0.3 \mathrm{mg}$ $\mathrm{L}^{-1}$ respectively (see below for measurement and determination of solutes).

For each of the four sites (as, gt, sb, sf), we then mixed stream water, bacterial inoculum (5\% vol.), and the DOC solution at a fixed volume. To reach six different DOC:nitrate-N and DOC:SRP start ratios for each of the four stream sites (as, gt, sb, sf), we added Alder DOC stock solution at different dilutions, using deionized water for the dilution. For each of the stream sites, the final solutions contained $0.02 \%$ (equivalent to $\left.0.8 \mathrm{mg} \mathrm{L}^{-1}\right), 0.2 \%\left(7.6 \mathrm{mg} \mathrm{L}^{-1}\right), 0.4 \%(15.2 \mathrm{mg}$

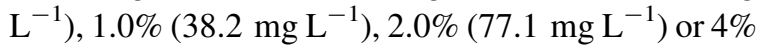
(157.5 mg L $\mathrm{m}^{-1}$ ) of the original concentration of the Alder DOC stock solution. With that and the different nutrient concentrations of the stream water samples, we reached a range of different DOC:nitrate-N (0.3 to 694.6) and DOC:SRP (22.3 to 1026.2) molar ratios.

We established one start solution for all replicates of each DOC solution treatment and stream. We split this start solution into aliquots of $150 \mathrm{~mL}$ per replicate (three replicates per stream-treatment combination). We ran the experiment in $150 \mathrm{~mL}$ brown-glass vials, washed thoroughly with distilled water before the experiment. The $150 \mathrm{~mL}$ brown-glass vials were constantly shaken at 89 revolutions per minute in the dark at $18{ }^{\circ} \mathrm{C}$. In the experiment, we measured DOC and nutrient concentrations at the start of the experiment, and after $60 \mathrm{~h}$, a time at which previous, similar experiments have proven maximum bacterial reaction to Alder leaf leachate DOC (Graeber et al. 2018).

In an additional control treatment, we measured how the inoculum influenced the experimental nutrient and DOC concentrations. We measured inoculum concentrations of DOC and nutrients without Alder leaf leachate for each stream at both sampling times with three replicates. To separate inoculum effects from the treatment effects, we subtracted the DOC or nutrient concentration means of the inoculum control 
from the values of the respective stream-date combination of each treatment.

Solute sample analysis

After sampling, we filtered all solute samples with prerinsed (1 L DI water) $0.22 \mu \mathrm{m}$ polycarbonate membrane filters (Membrapure, Gelman). Subsequently, we analyzed the concentrations of ammonium-N, nitrite-N, nitrate-N, and SRP by segmented-flow analysis (Skalar) photometrically, with quantification limits of $0.011,0.006,0.042$, and $0.003 \mathrm{mg} \mathrm{L}^{-1}$, respectively. We measured DOC concentration as $\mathrm{CO}_{2}$ in the near infrared after acidification stripping out the DIC by high-temperature catalytic oxidation (DIMATOC 2000 from DIMATEC, Germany), with a quantification limit of $0.50 \mathrm{mg} \mathrm{L}^{-1}$.

We determined total dissolved $\mathrm{N}$ (TDN) after persulfate oxidation photometrically after reduction as nitrite- $\mathrm{N}$ complex in the segment-flow analysis with a quantification limit of $0.042 \mathrm{mg} \mathrm{L}^{-1}$. Here, we also determined total dissolved phosphorus (TDP) after oxidation of all $\mathrm{P}$ containing compounds to SRP as organo-phosphorous complex photometrically (Hach DR 5000) with a quantification limit of $0.006 \mathrm{mg} \mathrm{L}^{-1}$.

We measured DOM composition by EEMs (Horiba Aqualog, USA) in 1-cm Quartz glass cuvettes. We used an excitation range from 255 to $600 \mathrm{~nm}$, and an emission range from 240 to $621 \mathrm{~nm}$ with an integration time of $0.72 \mathrm{~s}$, medium CCD gain, an excitation increment of $5 \mathrm{~nm}$, an emission increment of $0.82 \mathrm{~nm}$, and an excitation slit width of $10 \mathrm{~nm}$. With the same instrument, we measured the light absorbance from 255 to $600 \mathrm{~nm}$ to correct the inner-filter effect (Kothawala et al. 2013; Murphy et al. 2013). The absorbance was always below $1 \mathrm{~cm}^{-1}$ at $240 \mathrm{~nm}$, a range at which the inner-filter effect can be efficiently removed (Kothawala et al. 2013).

\section{Data processing}

We conducted all data processing, PARAFAC modeling, statistics, and data plot building in $\mathrm{R}$, version 4.0.2 (R Core Team 2020).

For solute concentrations below the quantification limit (see above for quantification limits), we randomly chose one number from 0 to the respective quantification limit, based on a uniform distribution (function runif in R).
We calculated DON as TDN-(nitrate- $\mathrm{N}+$ ammonium-N + nitrite-N) and DOP as TDP-SRP. The indirect determination of DON and DOP can result in considerable DON and DOP concentration uncertainty (as exemplified for DON, Graeber et al. 2012a). We used a DIN:TDN versus DON diagnostic plot or SRP:TDP versus DOP diagnostic plot to assess this uncertainty. We based this approach on Graeber et al. (2012a), where it has been shown that at DIN:TDN < 0.6 DON concentrations can be trusted; that at DIN:TDN ratios $=0.6$ to 0.8 systematic deviations of the estimated DON concentrations from the true DON concentrations can occur; that DIN:TDN ratios $>0.8$ are indicative of high random and systematic uncertainty; and that DIN:TDN ratios $>1$ indicate an overestimation of DIN, resulting in negative DON concentrations. We assume the same thresholds for DOP and SRP:TDN. Based on the diagnostic plots, we found that most water samples had considerably high DON concentrations and exhibited DIN:TDN ratios $<0.6$ (Fig. S1). In contrast, DOP concentrations were generally low, or even negative, with most water samples having SRP:TDP ratios $>0.8$. Based on these diagnostic plots, we assume DON concentrations to be relatively trustworthy, while this is not the case for DOP concentrations. Furthermore, we found considerable DON but not DOP in the Alder leaf leachate (see above) and stream water samples (Table 1). Based on the probable high uncertainty of determined DOP concentrations and its concentration irrelevance compared to SRP, we excluded DOP from any further data analysis and calculations of stoichiometric ratios. We also assumed that SRP represented the reactive P pool sufficiently due to the low apparent DOP concentrations.

To prepare the EEMs for the PARAFAC, we subtracted the blank water fluorescence and removed the inner-filter effect with the Horiba Aqualog software package (version 4.0) using the absorbancebased approach (Kothawala et al. 2013). We converted the EEM measurements to Raman units within the staRdom package (Pucher et al. 2019), based on the approach by Lawaetz and Stedmon (Lawaetz and Stedmon 2009). Here, we used an excitation wavelength of $350 \mathrm{~nm}$ and an emission range of 371 to $428 \mathrm{~nm}$. To remove Rayleigh and Raman scatter, we used the scatter removal and interpolation approach in staRdom (Pucher et al. 2019), which usually results in the best extractable fluorophore spectra (Bahram et al. 
Table 1 Dissolved macronutrient composition of samples at the start of the experiment, before additions of Alder leaf leachate

\begin{tabular}{lccllllllr}
\hline Stream & DOC & Nitrate-N & Nitrite-N & Ammonium-N & DON & SRP & DOP & DOC:nitrate-N & DOC:SRP \\
\hline Asse (as) & 3.35 & 10.40 & 0.05 & 0.04 & 0.21 & 0.04 & 0.02 & 0.4 & 210.7 \\
Getel (gt) & 8.58 & 1.68 & 0.01 & 0.02 & 1.13 & 0.99 & 0.01 & 6.0 & 22.4 \\
Sauerbach (sb) & 4.87 & 0.57 & 0.05 & 0.13 & 0.56 & 0.19 & 0.01 & 10.0 & 64.7 \\
Ströbecker Fließ (sf) & 6.87 & 0.41 & 0.04 & 0.03 & 0.63 & 0.01 & 0.02 & 19.6 & 1265.4 \\
\hline
\end{tabular}

Concentrations are in $\mathrm{mg} \mathrm{L}^{-1}$, ratios are molar

2006). Here, we removed a width of $15 \mathrm{~nm}$ for the $1 \mathrm{st}$ order Rayleigh, and Raman scatter and a width of $20 \mathrm{~nm}$ for the 2 nd order Rayleigh and Raman scatter. Subsequently, we interpolated the removed fluorescence data by spline interpolation (Pucher et al. 2019).

To chemometrically extract the DOC fluorophores from the EEMs, we established a PARAFAC model in the staRdom package (Pucher et al. 2019) based on the rules outlined in Pucher et al. (2019) and Murphy et al. (2013). In short, we developed the PARAFAC model based on split-half validation, spectral shapes of the fluorophores, assessment of sample and wavelength model leverage, residual fluorescence assessments, and global minimum model error assessment based on 200 random model starts. We attributed the fluorophore by spectral shape comparison to the OpenFluor database (Murphy et al. 2014) and other literature.

\section{Statistical evaluations of the experiment}

To determine the relations between DOC:nitrate-N, DOC:reactive $\mathrm{N}$, or DOC:SRP molar ratios and relative nitrate or SRP uptake for the first experiment, we used a logistic model derived from the conceptual models of Taylor \& Townsend (Taylor and Townsend 2010) and Stutter et al. (2018):

$$
U_{\text {nitrate } N} \%=\frac{C}{1+a \cdot e^{-k \cdot D O C: \text { nitrate }-N_{\text {start }}}}
$$

Here, $\mathrm{U}_{\text {nitrateN\% }}$ is the uptake of nitrate- $\mathrm{N}$ relative to the start value of nitrate- $\mathrm{N}$, and $\mathrm{C}$, a and $\mathrm{k}$ are constants, where $\mathrm{C}$ indicates the maximum uptake. This form is analogous for SRP and reactive N. Hence, $\mathrm{U}_{\text {nitrateN\% }}$ is substituted with $\mathrm{U}_{\mathrm{SRP} \%}$ and DOC:nitrate$\mathrm{N}_{\text {start }}$ is substituted with DOC:SRP start $_{\text {. We calculated }}$ the inflection point as $\log 10(\mathrm{a}) / \mathrm{k}$, which equals the steepest slope in logistic models. To assess the fit of the logistic model, we calculated the $\mathrm{R}^{2}$ based on the total sum of squares (TSS) and the sum of squared errors (SSE), as:

$R^{2}=1-\frac{S S E}{T S S}$

To link DOC composition and the amount of bioavailable bDOC or bioavailable bDON, we investigated the correlation between the uptake of DOC or DON and the uptake of the PARAFAC components. Here, a positive correlation indicates the dependence of DOC uptake on the uptake of a specific PARAFAC component, a negative correlation indicates the accumulation or production of a PARAFAC component during DOC processing, and no correlation indicates independence of DOC uptake from a given PARAFAC component. To construct and evaluate linear correlations between DOC uptake and a specific PARAFAC component, we used the summary. $1 \mathrm{~m}$ and $\operatorname{lm}()$ functions within R. The samples used for linear regression were independent of each other, and the residuals were homogeneously distributed; hence the assumptions of the linear models were valid. Furthermore, the assumptions of the logistic growth model were valid, as the model represented the distribution of the data well, and underlying samples were independent of each other.

If a specific PARAFAC component exhibited a consistent positive correlation with DOC or DON uptake for all stream waters, we deemed it representative of a bioavailable moiety of DOC or DON. Based on this assumption, we calculated the concentration of bDOC for each sample separately as:

bDOC $=\frac{\sum_{i=1}^{n} C b_{i}}{\sum_{i=1}^{m} \text { Comp }_{i}} \cdot D O C$

Here $\mathrm{Cb}$ is the fluorescence (in R.U.) of a bioavailable PARAFAC component, $\mathrm{n}$ is the total 
number of bioavailable PARAFAC components, Comp is the fluorescence of every PARAFAC component, and $\mathrm{m}$ is the total number of PARAFAC components. This calculation assumes that the ratio of the fluorescence of the bioavailable components to the total fluorescence equals the ratio of the concentration of bioavailable DOC to total DOC. In other words, we assume that EEM-PARAFAC based bDOC represents all bDOC. Based on the bDOC calculated from EEMPARAFAC, we subsequently assessed with a linear correlation how well it represents the DOC uptake during the experiment.

For bioavailable DON (bDON), we conducted an analogous calculation:

$$
b D O N=\frac{\sum_{i=1}^{n} C b_{i}}{\sum_{i=1}^{m} C_{O M p}} \cdot D O N
$$

Similarly to bDOC, we assumed that the uptake of the PARAFAC components was representative of the bDON contribution to bulk DON. Again, we assessed this assumption in the same way as for bDOC; hence, how well the calculated bDON correlated to the measured DON uptake. Finally, we calculated the total reactive $\mathrm{N}$ pool as follows:

$$
\begin{aligned}
\text { reactive } N= & (\text { nitrate }-N+\text { nitrate }-N \\
& + \text { ammonium }-N)+b D O N
\end{aligned}
$$

Here, we assumed that all DIN is reactive and that the total dissolved reactive $\mathrm{N}$ pool is the sum of DIN and bDON. We further assumed that all reactive $\mathrm{P}$ equals SRP due to only very low, uncertain concentrations of DOP (see also explanation above in the Data Processing section). Finally, we determined the link between bDOC:reactive N or bDOC:SRP ratios and nitrate-N or SRP uptake with the same non-linear model approach used for bulk DOC above.

We constructed ternary plots for which we normalized the bDOC, reactive $\mathrm{N}$ and $\mathrm{P}$ calculated above with the Godwin-Cotner molar ratio (GCR) of $68 \mathrm{C}: 14 \mathrm{~N}: 1 \mathrm{P}$. The GCR is the median C:N:P of 137 isolates of lake planktonic bacteria grown under non-limiting conditions (Godwin and Cotner 2018). For the normalization, we used the bDOC, reactive $\mathrm{N}$ and $\mathrm{P}$ concentrations at the start of the experiment. For the GCR-normalized ternary plots, we calculated the contributions of molar concentrations $(\mathrm{mM}=\mathrm{mmol}$ $\mathrm{L}^{-1}$ ) of bioavailable DOC, reactive $\mathrm{N}$, and reactive $\mathrm{P}$ as follows:
$\% b D O C$

$$
=\frac{b D O C / 68}{(\text { bDOC } / 68)+(\text { reactive } / 14)+\text { reactiveP }}
$$

\%reactiveN

$$
=\frac{\text { reactive } N / 14}{(\text { bDOC } / 68)+(\text { reactiveN } / 14)+\text { reactiveP }}
$$

\%reactiveP

$$
=\frac{\text { reactive } P / 14}{(\text { bDOC } / 68)+(\text { reactive } N / 14)+\text { reactive } P}
$$

\section{Results}

Solute concentrations of stream water samples and bacterial inocula

High variability of nitrate-N, SRP, DOC, and DON concentrations, and comparably low ammonium-N, nitrite-N, and DOP concentrations characterized the streams (Table 1). Based on those concentrations, and before the addition of Alder leaf leachate DOC for the experiment, the DOC:nitrate-N and DOC:SRP molar ratios varied widely (Table 1 ).

We used a control with the standardized 5\% volume of inoculum, mixed with DI water, to assess bacterial inoculum effects on the solute concentrations. Based on the averages for each stream and sampling time, the bacterial inoculum added $<0.01 \mathrm{mg} \mathrm{N} \mathrm{L}^{-1}$ nitrite and $<0.02 \mathrm{mg} \mathrm{N} \mathrm{L}^{-1}$ ammonium. Moreover, we found that it added between $<0.04-0.97 \mathrm{mg} \mathrm{N}$ $\mathrm{L}^{-1},<0.01-0.07 \mathrm{mg} \mathrm{P} \mathrm{L}^{-1}$ and $<0.50-0.89 \mathrm{mg} \mathrm{C}$ $\mathrm{L}^{-1}$ of nitrate, SRP and DOC, respectively. This addition of nutrients by the bacterial inocula was considerable, but much less than the start values of the stream water samples in most cases (Table 1). Since we subtracted the inoculum control values from the treatments, the effects of DOC and released nutrients from the inoculum on the experimental results were minor. However, for the Ströbecker Fließ, we found an increase of on average $0.30 \mathrm{mg} \mathrm{L}^{-1}$ nitrate- $\mathrm{N}$ in the control. This increase resulted in high negative values 
of relative nitrate uptake for all replicates of one treatment of Ströbecker Fließ $\left(0.8 \mathrm{mg} \mathrm{L}^{-1}\right.$ DOC addition).

Effects of bulk DOC:nutrient ratios on nutrient uptake

The logistic model fitted the data well for both the link between DOC:nitrate-N and nitrate-N uptake (Fig. 2a) and the link between DOC:SRP and SRP uptake (Fig. 2b). The DOC:Nitrate-N logistic model showed a slope increase in $\mathrm{N}$ uptake rate above a DOC:nitrate$\mathrm{N}$ ratio of $\sim 7$ and a slope decrease above a DOC:nitrate-N ratio of $\sim 35$. We found the inflection point (point of steepest slope, calculated as $\log 10(\mathrm{a}) / \mathrm{k}$; see Eq. 1) at a DOC:nitrate-N ratio of 24. Similarly, the DOC:SRP logistic growth model showed an apparent slope increase in $\mathrm{P}$ uptake rate above a DOC:SRP ratio of $\sim 100$, and a clear slope decrease above a DOC:SRP ratio of $\sim 400$. We found the inflection point of the logistic model at a DOC:SRP ratio of 271. This behaviour was clearly followed by three of the four stream sites, however stream site "sf" showed a steep decline in SRP uptake at a bulk DOC:SRP above 300.

Effects of DOC composition and bioavailable DOC:Nutrient ratios on nutrient uptake

We found five PARAFAC components, whose spectra linked to different DOC types (Table 2, see Fig. S2 in supplement for full spectra). Three of the five
PARAFAC components were ubiquitously found in several ecosystems; two of them are rarely found (Table 2).

Of the PARAFAC components, $\mathrm{C}_{\mathrm{T}}, \mathrm{C}_{\mathrm{LL}}$, and $\mathrm{C}_{\mathrm{X}}$ correlated positively with DOC uptake within all four stream waters $\left(r^{2}>0.74, p<0.001\right.$, Fig. $3 c, g$, i, see Table S1 in the electronic supplementary material for fit parameters). This positive correlation indicates that microbiota removed these moieties together with bulk DOC. Contrarily, $\mathrm{C}_{\mathrm{H}-\mathrm{UV}}$ correlated negatively with DOC uptake for all four stream waters $\left(r^{2}>0.88\right.$, $\mathrm{p}<0.001$, Fig. 3e), indicating that this component was produced when bulk DOC was removed. In comparison to the other PARAFAC components, $\mathrm{C}_{\mathrm{H}}$ showed a mixed response, as for two stream waters, $\mathrm{C}_{\mathrm{H}}$ correlated negatively with DOC uptake ( $\mathrm{sf}$ and $\mathrm{sb}$, $\mathrm{r}^{2}>0.47, \mathrm{p}<0.006$, Fig. 3a), whereas $\mathrm{C}_{\mathrm{H}}$ was not correlated to DOC uptake within the other two stream waters (as and gt, $\mathrm{r}^{2}<0.08, \mathrm{p}>0.05$, Fig. 3a).

For DON uptake, we found the same patterns of correlation as for DOC uptake. Hence, $\mathrm{C}_{\mathrm{T}}, \mathrm{C}_{\mathrm{LL}}$, and $\mathrm{C}_{\mathrm{X}}$ correlated positively with DON uptake within all four stream waters $\left(r^{2}>0.46, p<0.002\right.$, Fig. $3 d, h, j$, see Table $\mathrm{S} 2$ in the electronic supplementary material for fit parameters). $\mathrm{C}_{\mathrm{H}-\mathrm{UV}}$ correlated negatively with DON uptake for all four stream waters $\left(r^{2}>0.61\right.$, $\mathrm{p}<0.001$, Fig. 3f). $\mathrm{C}_{\mathrm{H}}$ showed a mixed response. $\mathrm{C}_{\mathrm{H}}$ correlated negatively with DON uptake (Ströbecker Fließ and Silstedter Bach, $\left.r^{2}>0.34, p<0.01\right)$, whereas $\mathrm{C}_{\mathrm{H}}$ was not correlated to DON uptake within the other two stream waters (as and gt, $\mathrm{r}^{2}<0.09$, $\mathrm{p}>0.05$, Fig. 3b).

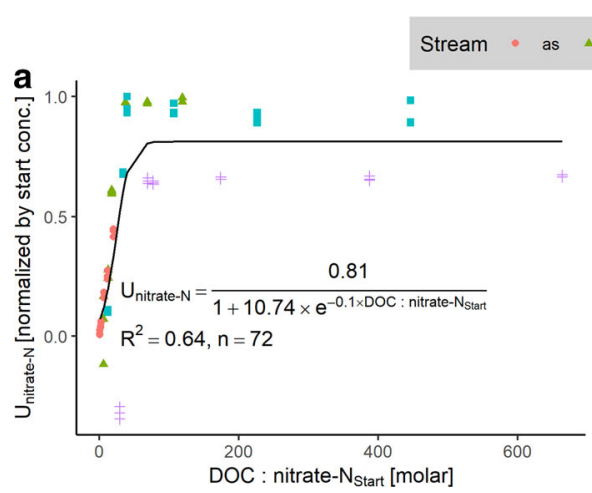

Fig. 2 Effect of bulk DOC:nitrate-N or bulk DOC:SRP ratios at the start of the experiment on the relative uptake of nitrate- $\mathrm{N}$ or SRP during the experiment. The line represents the logisticmodel fit. The uptake of nitrate-N and SRP was normalized (termed relative) to the respective start concentration of each

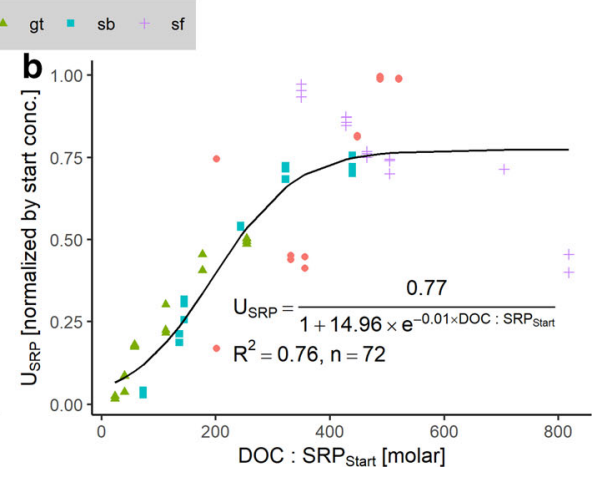

nutrient to account for the high variability of nitrate- $\mathrm{N}$ and SRP concentrations between the streams (Table 1), and to test for the prediction on the change in relative nutrient uptake by DOC:nitrate-N ratios presented in Fig. 1 
Table 2 EEM-PARAFAC fluorophore abbreviations, their core spectral characteristics, and comments on their type or source

\begin{tabular}{|c|c|c|c|}
\hline $\begin{array}{l}\text { Fluorphore } \\
\text { number }\end{array}$ & Fluorphore name & $\begin{array}{l}\text { Spectral } \\
\text { characteristics } \\
(\mathrm{nm})\end{array}$ & Comments \\
\hline 1 & Humic-like $\left(\mathrm{C}_{\mathrm{H}}\right)$ & $\begin{array}{l}\mathrm{Ex}_{\max }<255 \\
\mathrm{Em}_{\max }=456\end{array}$ & Common humic like, rather refractory (Fellman et al. 2010) \\
\hline 2 & $\begin{array}{l}\text { Tryptophan-like } \\
\left(\mathrm{C}_{\mathrm{T}}\right)\end{array}$ & $\begin{array}{l}\mathrm{Ex}_{\max }=275 \\
\mathrm{Em}_{\max }=330\end{array}$ & $\begin{array}{l}\text { Common tryptophan/ protein like, microbially produced, bioavailable } \\
\text { (Fellman et al. 2010) }\end{array}$ \\
\hline 3 & $\begin{array}{l}\text { UV-shifted humic } \\
\text { like }\left(\mathrm{C}_{\mathrm{H}-\mathrm{UV}}\right)\end{array}$ & $\begin{array}{l}\mathrm{Ex}_{\max }<255 \\
\mathrm{Em}_{\max }=395\end{array}$ & $\begin{array}{l}\text { Common UV-shifted humic like, rather refractory (Fellman et al. 2010; } \\
\text { Nimptsch et al. 2015) }\end{array}$ \\
\hline 4 & $\begin{array}{l}\text { Leaf leachate } \\
\qquad\left(\mathrm{C}_{\mathrm{LL}}\right)\end{array}$ & $\begin{array}{l}\mathrm{Ex}_{\max }=315 \\
\mathrm{Em}_{\max }=424\end{array}$ & $\begin{array}{l}\text { Less common humic-like peak, found in leaf leachates, potentially } \\
\text { bioavailable (Williams et al. 2010; Wheeler et al. 2017) }\end{array}$ \\
\hline 5 & $\begin{array}{l}\text { Dark-incubation } \\
\text { peak }\left(\mathrm{C}_{\mathrm{X}}\right)\end{array}$ & $\begin{array}{l}\mathrm{Ex}_{\max }=400 \\
\mathrm{Em}_{\max }=477\end{array}$ & $\begin{array}{l}\text { Rarely found peak, sensitive to dark incubations in lakes (Kothawala et al. } \\
\text { 2012) }\end{array}$ \\
\hline
\end{tabular}

Please see the supplement for full spectra

Above, we have shown that three PARAFAC components were consistently available for heterotrophic uptake $\left(\mathrm{C}_{\mathrm{T}}, \mathrm{C}_{\mathrm{LL}}, \mathrm{C}_{\mathrm{x}}\right.$; Fig. 3). Hence, using Eq. 3 and 4, we calculated bDOC and bDON based on $\mathrm{C}_{\mathrm{T}}, \mathrm{C}_{\mathrm{LL}}, \mathrm{C}_{\mathrm{x}}$, whereby bDOC was very well correlated to the actual DOC uptake during the experiment $\left(\mathrm{R}^{2}=0.96\right.$; Fig. 4a). However, bDON was also well correlated with a diminished explained variance $\left(\mathrm{R}^{2}=0.77\right.$, Fig. $\left.4 \mathrm{~b}\right)$. The linear model indicated that the bDOC concentration slightly overestimated the actual DOC uptake (slope $=0.6$; Fig. 4 a). The same effect was apparent for bDON and the actual DON uptake (slope $=0.52$, Fig. $4 b$ ).

When using bDOC and reactive $\mathrm{N}$ - the sum of DIN and bDON_we found a shift in the range of $\mathrm{x}$-axis (Fig. 5a). However, for reactive $\mathrm{P}$ uptake (in our study reactive $\mathrm{P}$ equals SRP for reasons mentioned in the methods), we found a similar type of reaction of nutrient uptake to changes in bDOC (Fig. 5b, see effects of bioavailable PARAFAC components on nitrate-N and SRP uptake in Fig. S3) compared to bulk DOC and SRP. Here, the fits were better for the bDOC:reactive $N\left(R^{2}=0.83\right.$, Fig. 5a) than for the bulk DOC:nitrate-N $\left(\mathrm{R}^{2}=0.64\right.$, Fig. $\left.2 \mathrm{a}\right)$ and slightly better for the bDOC:reactive $P\left(R^{2}=0.80\right.$, Fig. $\left.5 b\right)$ compared to the bulk DOC:SRP $\left(\mathrm{R}^{2}=0.76\right.$, Fig. $\left.2 \mathrm{~b}\right)$.

Compared to bulk DOC logistic models (Fig. 2), the nutrient uptake reacted already at lower bDOC:reactive nutrient ratios (Fig. 5a, b). In detail, the slope increase at the lower end of the logistic models appeared at bDOC:reactive nutrient ratios of approximately 2 and 50 for reactive $\mathrm{N}$ and reactive $\mathrm{P}$, respectively (Fig. 5a, b). Furthermore, the slope decrease at the upper end of the logistic models appeared already at an approximate value of 17 and 300 for bDOC:reactive $\mathrm{N}$ and bDOC:reactive $\mathrm{P}$, respectively (Fig. 5a, b). Moreover, in comparison to the bulk DOC:nutrient ratios (Fig. 2), the inflection point of the logistic models based on bDOC appeared earlier. We calculated the inflection points of the logistic models for the bDOC:reactive N or bDOC:reactive $\mathrm{P}$ as molar ratios of 8 and 160, respectively (Fig. 5a, b). As for bulk DOC:reactive P, stream site "sf" showed a decrease in reactive $P$ uptake at a bulk DOC:reactive P above 300 (Fig. 5a), albeit less steep than for bulk DOC:SRP (Fig. 2a).

Most of the highest uptake of reactive $\mathrm{N}$ occured at a specific range with lower $\mathrm{N}$, higher $\mathrm{C}$, and slightly lower $\mathrm{P}$ contribution, hence higher $\mathrm{C}: \mathrm{N}$ and slightly higher $\mathrm{C}: \mathrm{P}$, than the one of the GCR (top left in ternary plot, Fig. 6b). In most cases, the highest uptake of reactive $\mathrm{P}$ also occurred at a specific range, with higher $\mathrm{C}: \mathrm{P}$ and slightly higher $\mathrm{C}: \mathrm{N}$ than the one of the GCR (top left in ternary plot, Fig. 6c). An exception to this rule was the stream "sf", for which the reactive $\mathrm{P}$ uptake was not as high in the zone of maximum uptake as detected for the other streams (Fig. 6c). For all streams, the uptake was below the detected maximum at the top of the ternary plot, hence did not reach its maximum at a N:P similar to the GCR (Fig. 6b, c). 

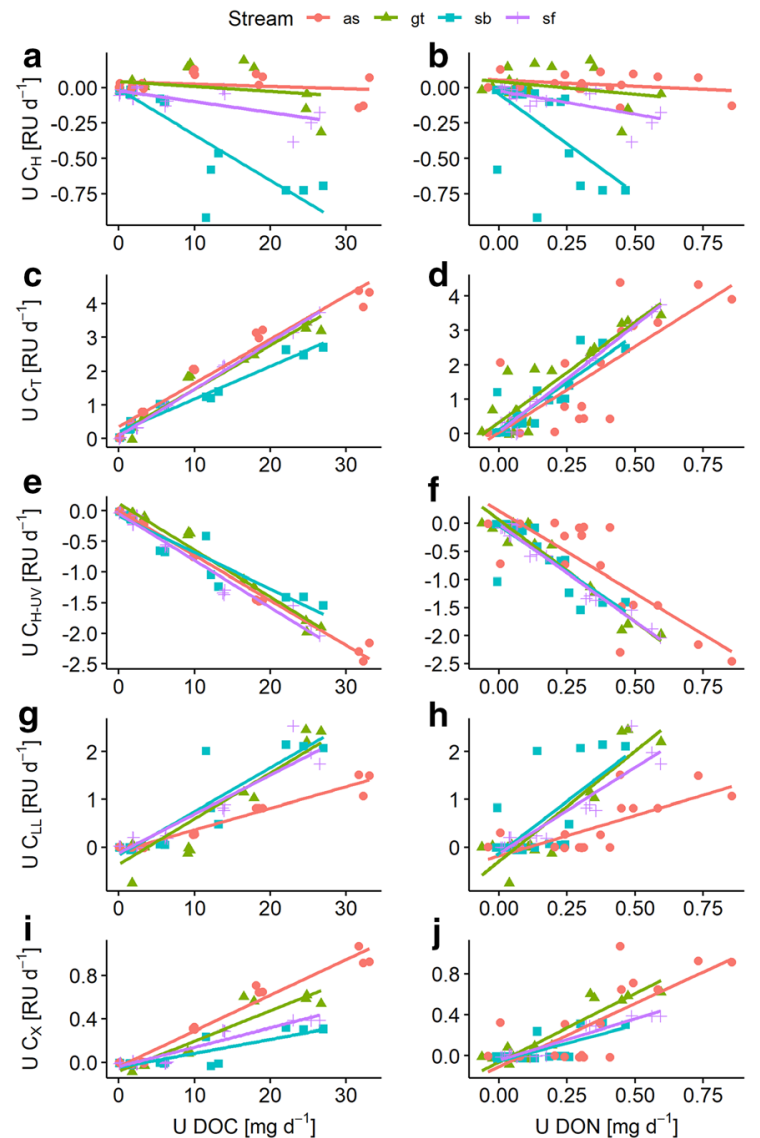

Fig. 3 Linear regressions between DOC uptake (U DOC, panels a, c, e, $\mathbf{g}, \mathbf{i}$ ) or DON uptake (U DON, panels $\mathbf{b}, \mathbf{d}, \mathbf{f}, \mathbf{h}, \mathbf{j}$ ) and EEM-PARAFAC fluorophore uptake $\left(\mathrm{U} \mathrm{C}_{\mathrm{H}}\right.$.. $\left.\mathrm{U} \mathrm{C}_{\mathrm{X}}\right)$ during the experiment. Linear regressions were done separately for each stream water source and EEM-PARAFAC fluorophore $(\mathrm{n}=18)$

\section{Discussion}

Our experimental results strongly support the relationship proposed by earlier empirical studies for DOC:nutrient ratios and assimilatory nutrient uptake (Hypothesis 1). Specific PARAFAC components represented bioavailable DOC, and by using those components, we successfully calculated and validated bDOC:reactive nutrient ratios strongly affecting reactive nutrient uptake (Hypothesis 2). Finally, for our four investigated streams, we found largely consistent zones of bDOC:reactive $\mathrm{N}$ :reactive $\mathrm{P}$ ratios at which we found either limitation of nutrient uptake by single reactive nutrients, or reactive nutrient co-limitation (Hypothesis 3).

For our experiment, we could validate the macronutrient-access hypothesis that DOC:reactive $\mathrm{N}$ and DOC:reactive $\mathrm{P}$ control reactive $\mathrm{N}$ and $\mathrm{P}$ assimilation by microbial heterotrophs. Specifically, the GCRnormalized ternary plots enabled us to constrain zones of reactive nutrient limitation and co-limitation resulting in mostly well-defined areas of predictable reactive nutrient assimilation relative to the assumed bacterial $\mathrm{C}: \mathrm{N}: \mathrm{P}$ demand (conceptually summarised in Fig. 7). We found a zone of maximum reactive $\mathrm{N}$ uptake (C:N:P approx. $>114:<9: 1$ ), reactive $\mathrm{P}$ uptake (C:N:P approx. $>170: 21:<1$ ), and reactive $\mathrm{N}$ and $\mathrm{P}$ co-limitation of nutrient uptake (C:N:P approx. $>$ 204:14:1) (Fig. 7). These three zones also depict the advantage of GCR-normalized ternary plots over classic biplots, as the co-limitation zone would have been hard to visualize in such plots. The GCR ratio,

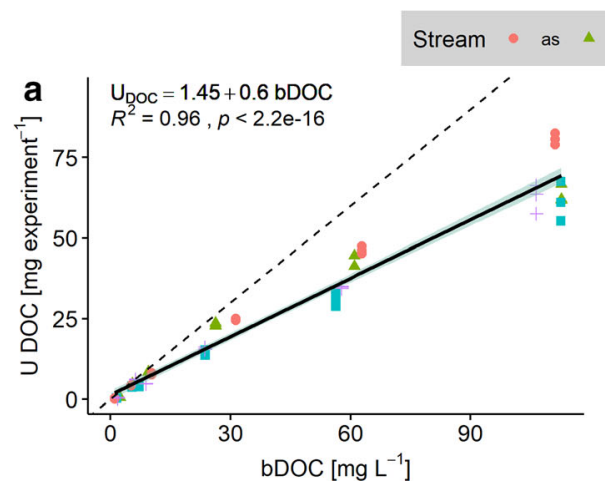

Fig. 4 Linear regressions between bioavailable DOC or DON (bDOC or bDON calculated based on PARAFAC components available for uptake $\left(\mathrm{C}_{\mathrm{T}}, \mathrm{C}_{\mathrm{LL}}, \mathrm{C}_{\mathrm{X}}\right)$ according to Eqs. 3, 4), and

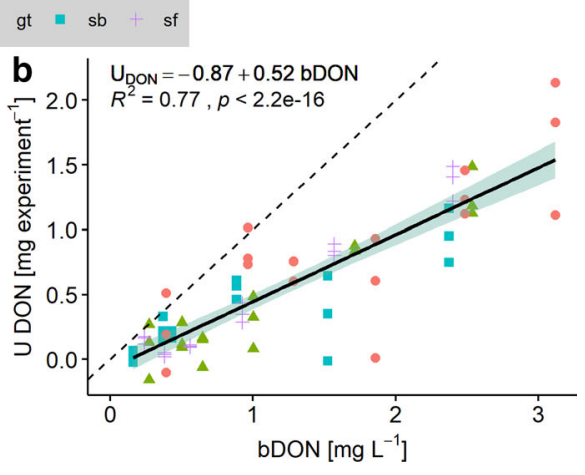

the actual DOC uptake (U DOC; a) or DON uptake (U DON; b) during the experiment $(n=72)$. The segmented line represents a $1: 1$ relationship 

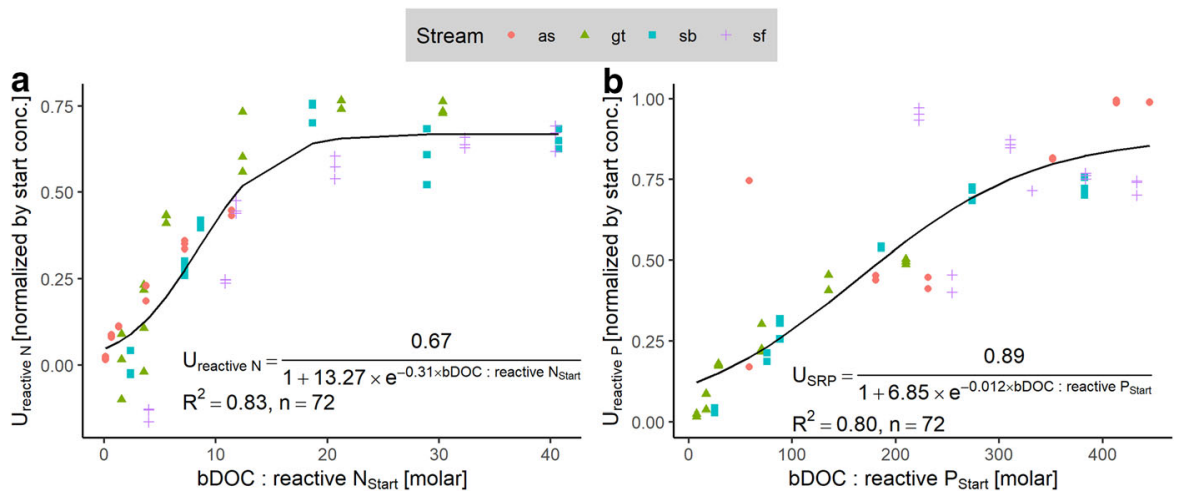

Fig. 5 Correlations between the molar bDOC:reactive $\mathrm{N}$ (a) or bDOC:reactive $\mathrm{P}$ (b) ratios at the start of the experiment (see Eq. 3 and Eq. 4 for the calculation of the bDOC and bDON concentrations) and the relative uptake of reactive $\mathrm{N}$ or $\mathrm{P}$ during the experiment. The line represents the fit of a logistic model (Eq. 1). The uptake of reactive $\mathrm{N}$ and $\mathrm{P}$ was normalized to the

although not determined specifically for our streams, worked astonishingly well in predicting this colimitation zone. In fact, it was calculated as median $\mathrm{C}: \mathrm{N}: \mathrm{P}$ of bacterioplankton strains, isolated from nine lakes in the US, and incubated under non-limiting conditions (Godwin and Cotner 2018). In this study, Godwin and Cotner (2018) also pointed out the considerable variability of bacterial strains around the median $\mathrm{C}: \mathrm{N}: \mathrm{P}$. Here, C:P often is more variable than C:N (see also Fig. 6; Tezuka 1990; Vrede et al. 2002; Makino and Cotner 2004), although, other studies also found relative $\mathrm{P}$ uptake to be P-limited between C:P ratios of $>100-400$ (Tezuka 1990). Still, the GCR worked well for our experiment, indicating that reactive nutrient limitation occurs at freshwater ecosystem-independent ranges, maybe due to the fact that even in different freshwater ecosystems, similar dominant bacterial strains are selected by similar C:N:P ratios (Danger et al. 2008). Such ecosystem independence due to bacterial community adaptation would simplify predictions of C:N:P limitation of heterotrophic reactive nutrient uptake. However, our four sites are not sufficient to prove this notion of cross-system C:N:P limitation robustness and further studies should consider linking stoichiometry-based work to bacterial identity and community composition measurements (e.g. based on 16S-RNA) to investigate its validity.

We found a large area of flexible microbial reaction to macronutrient stoichiometric ratios resulting in a wide range of (co-)limited reactive nutrient uptake, respective start concentration of each nutrient to account for the high variability of reactive $\mathrm{N}$ and $\mathrm{P}$ concentrations (see Eq. 5) between the streams (Table 1), and to test for the prediction of the change in relative nutrient uptake by the macronutrientaccess hypothesis (Fig. 1)

which was predicted by earlier studies based on monitoring data (Taylor and Townsend 2010; Helton et al. 2015; Stutter et al. 2018) (Fig. 7). The wide potential range of $\mathrm{C}$ :nutrient ratios of bacterial communities likely generates this large microbial flexibility zone. Here, our results on the flexibility of the bacterial reaction support earlier notions that Liebig's law of the minimum is not applicable for stoichiometric constraints of bacterial communities and that instead, a wide range of gradual nutrient limitation constraints heterotrophic microbial nutrient uptake until the physiological limit of bacterial nutrient assimilation is reached (Danger et al. 2008).

Our experiment does not tackle how shifts in DOM composition (Asmala et al. 2014) or macronutrient stoichiometry (del Giorgio and Cole 1998; Asmala et al. 2014) might affect the ratio of microbial assimilation to respiration, hence the microbial growth efficiency. It has been shown in experiments that the bacterial growth efficiency is 40-60\% for good food source quality, hence low C:N and C:P and with high availability of labile DOC (Asmala et al. 2014). In contrast, with pre-degraded DOC and higher C:N and $\mathrm{C}: \mathrm{P}$, this efficiency is reduced to $<20 \%$ (Asmala et al. 2014). The microbial growth efficiency is decisive for the $\mathrm{C}: \mathrm{N}$ and $\mathrm{C}: \mathrm{P}$ ratio, at which DOC availability controls $\mathrm{N}$ and $\mathrm{P}$ uptake. Thus, assessing the links between microbial growth efficiency and $\mathrm{N}$ and $\mathrm{P}$ uptake in future experiments would help further constraining the relation between labile DOC and heterotrophic assimilation of reactive $\mathrm{N}$ and $\mathrm{P}$. 


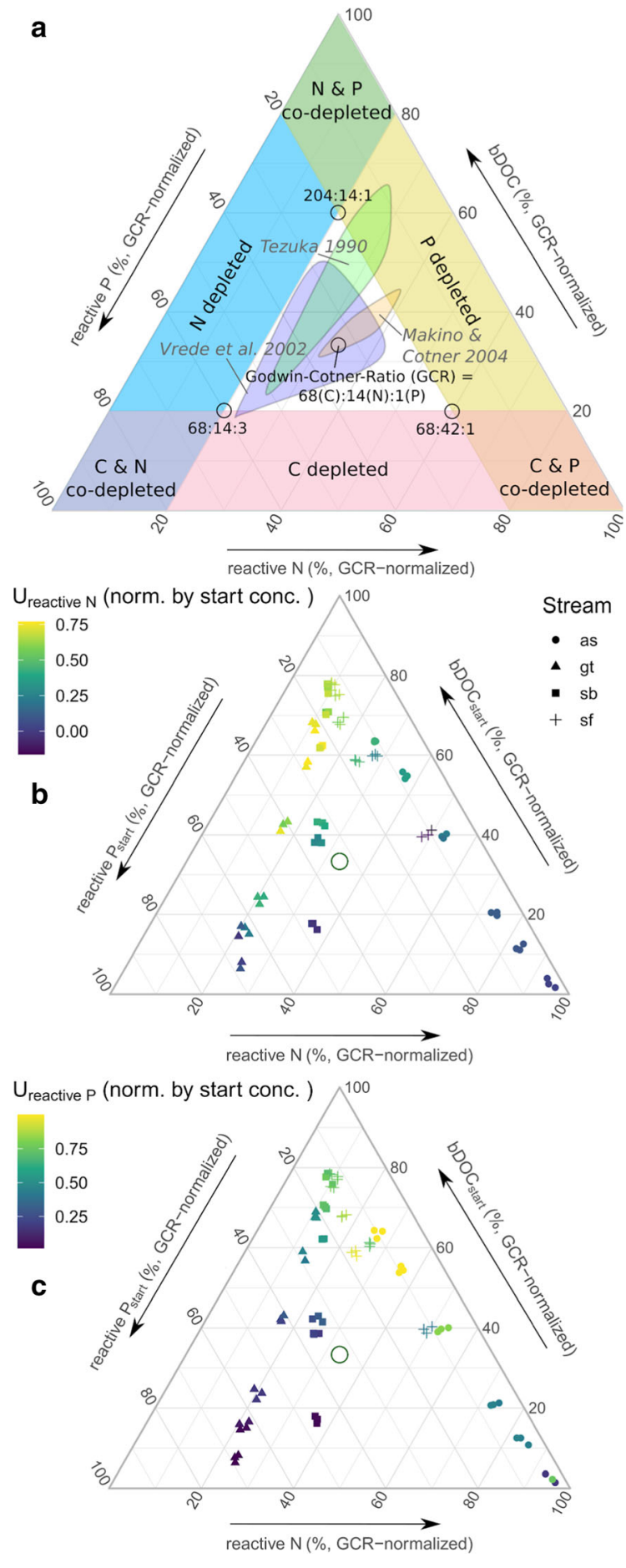

We found only a specific zone below the GCR ratio in which the microbial uptake of nutrients was not affected by the bDOC:nutrient ratio, potentially resulting in higher $\mathrm{N}$ and $\mathrm{P}$ concentrations (Fig. 7).
४Fig. 6 Godwin-Cotner-Ratio (GCR)-normalized ternary plots of reactive $\mathrm{N}$ and reactive $\mathrm{P}$ uptake. In panel a, we show an introductory ternary plot with different ranges of bacterial biomass C:N:P, and ranges of potential C:N:P depletion. Panels b and c show GCR-normalized ternary plots with our experimental data on reactive $\mathrm{N}$ and reactive $\mathrm{P}$ uptake, respectively. Samples with the same treatment and from the same stream had the same start C:N:P and we inserted $4 \%$ jitter on each axis to make all samples distinguishable. We derived the GCR from Godwin and Cotner (Godwin and Cotner 2018) and added ranges of bacterial biomass $\mathrm{C}: \mathrm{N}: \mathrm{P}$ ratios under different limiting conditions in different aquatic ecosystems as transparent ranges for comparison (Tezuka 1990; Vrede et al. 2002; Makino and Cotner 2004). The colored ranges on the edges of the plot in panel a are $\mathrm{C}, \mathrm{N}$ and $\mathrm{P}$ depletion ranges relative to organism C:N:P proposed by Jarvie et al. (2018)

This finding supports earlier notions that a narrow band of $\mathrm{N}$ and $\mathrm{P}$ accrual in aquatic ecosystems may be, at least partially, due to $\mathrm{C}$ limitation of heterotrophic assimilation (Stutter et al. 2018). This zone was narrower for actual bioavailable DOC:reactive $\mathrm{N}$ ratios than has been proposed for bulk DOC:nitrate$\mathrm{N}$ ratios (Taylor and Townsend 2010; Helton et al. 2015). Within our experiment, we found the same difference when directly comparing bulk DOC:nitrate$\mathrm{N}$ ratios and bioavailable DOC:reactive $\mathrm{N}$ ratios (compare Figs. 2a, 5a). Moreover, we could show the same effect when comparing bulk DOC:SRP and bioavailable DOC:reactive P ratios (compare Figs. 2b, $5 b)$. This effect leads us to conclude that the actual range in which bacteria cannot assimilate available nutrients due to too low $\mathrm{C}$ :nutrient ratios is relatively narrow when accounting for the truly bioavailable DOC instead of the bulk DOC. Furthermore, we hypothesize that this zone is clearly predictable based on the bacterial $\mathrm{C}: \mathrm{N}: \mathrm{P}$, as indicated by the GCRnormalized ternary plots (Figs. 6, 7). As for the zones of high reactive nutrient (co-)uptake, our small dataset mandates further investigations of this finding.

In addition to the difference between bulk and bioavailable DOC, the fluorescence measurements and PARAFAC modeling allowed us to calculate the difference between bulk and bioavailable DON. Here, we found excellent (DOC) or good correlations (DON) between fluorescence-based bioavailable DOC and DON concentrations to the uptake of DOC and DON measured during the experiment (Fig. 4). It has already been shown that the fluorescence-based DOM composition is closely linked to DOM 


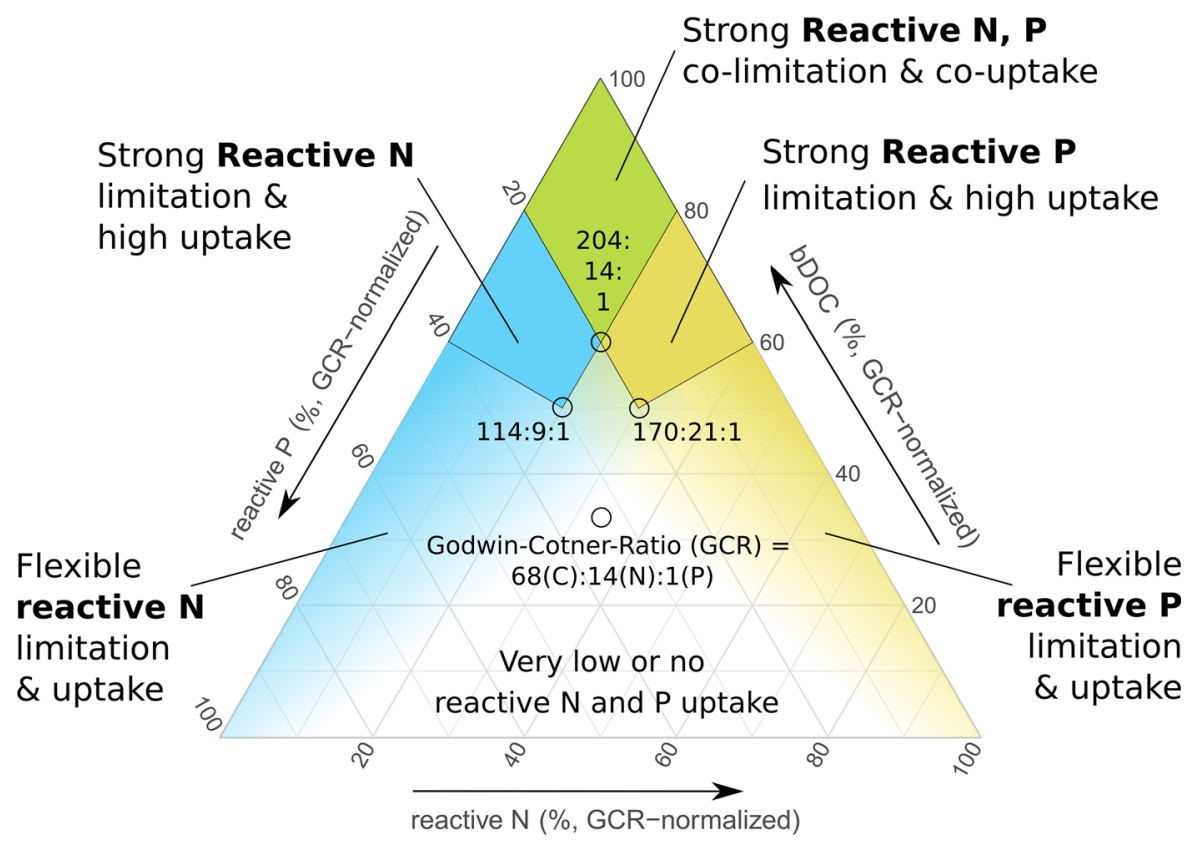

Fig. 7 Summary ternary plot of our results on the macronutrient-access hypothesis, with zones constrained by the experimental results of this study. We describe specific bioavailable (b)DOC:reactive N (DIN plus bDON) and bDOC:reactive P ratios (determined as bDOC:SRP in this study) at which we find the highest reactive $\mathrm{N}$ uptake and reactive $\mathrm{P}$ uptake, a zone with reactive $\mathrm{N}$ and $\mathrm{P}$ co-limitation, a zone of flexible $\mathrm{N}$ and $\mathrm{P}$ uptake

processing (e.g. Fellman et al. 2009, 2011); however, it has not yet been attempted to calculate bioavailable DOC and DON from that directly. This calculation requires the strong assumption that the bulk DOM pool has the same composition as the fluorescent DOM pool. In our experiment, this assumption holds, but this needs to be tested each time carefully before being applied. Still, our experiment shows the high value of DOM composition measurements for enlightening the effects of DOM composition on $\mathrm{C}$ and $\mathrm{N}$ biogeochemical cycling and stoichiometric effects. However, to fully understand the relationships between DOM composition and processing, one needs to combine fluorescence with in-depth DOM composition measurements, e.g., by Fourier-transform ion cyclotron mass spectrometry (Kamjunke et al. 2020). In addition, earlier studies show that strong links between bioavailability of DOC and DOM fluorophores (Petrone et al. 2011; Nimptsch et al. 2015) are also valid for various types of river waters, and also without higher concentrations of leaf leachates, but we encourage testing for further sites and on the links and a zone without considerable reactive $\mathrm{N}$ and $\mathrm{P}$ uptake. Our results imply that already small adjustments in the $\mathrm{C}: \mathrm{N}: \mathrm{P}$ ratio towards zones of high reactive $\mathrm{N}$ or reactive uptake or co-uptake may reduce freshwater nutrient concentrations and loads. However, potential secondary deleterious effects (e.g. eutrophication, increased greenhouse-gas emissions) of such shifts also are possible and need to be considered in further studies

between bioavailablity of DOM fluorophores and bioavailability of DON.

Our results indicate that DON can be of high importance for calculating the reactive $\mathrm{N}$ forms and that only using nitrate or even DIN is likely underestimating their concentration. Of the four agricultural streams sampled for this study, DON comprised around $50 \%$ of all dissolved $\mathrm{N}$ forms in two cases and more than $50 \%$ in one case (Table 1). DOP exhibited low concentrations in the stream waters sampled for our experiment (Table 1). However, at higher concentrations, DOP might also be of considerable importance for the reactive $\mathrm{P}$ pool. Based on these results, the organically bound dissolved $\mathrm{N}$ and $\mathrm{P}$ forms must be considered in freshwater studies if the stoichiometric constraints of heterotrophic assimilation should be assessed. Organic N and P forms are likely also of importance for stoichiometric constraints of algal growth, as many common freshwater algae are mixotrophic, and in the case of DON have been shown to grow even with complex molecular 
fractions (e.g., phytoplankton in lakes, Fiedler et al. 2015).

We determined DON indirectly, an approach that can result in high uncertainty (Siemens and Kaupenjohann 2002; Lee and Westerhoff 2005; Graeber et al. 2012a). Using diagnostic plots, we found this uncertainty to be acceptable for DON, but not for DOP, because of which we decided not to use DOP in our calculations (see Fig. S1 for diagnostic plots and also the Methods section). The high variability in the relationship between bDOC:reactive $\mathrm{N}$ and in the correlation of bDON with DON uptake likely is partially attributable to the random error induced by the indirect DON determination. For DON, DINremoval and direct DON measurement approaches have been shown to significantly reduce the determination uncertainty (Graeber et al., 2012a, 2012b). However, this has not yet been tested or achieved for DOP. We advocate that in aquatic systems in which substantial DON and DOP concentrations are to be expected, DON and DOP are ideally measured with high accuracy by advanced approaches, or at least that the determination uncertainty of their concentrations is estimated (e.g. by diagnostic plots as in Fig. S1 or by error propagation).

While the other stream sites followed similar patterns in the reaction of nitrate- $\mathrm{N}$ uptake to changes in DOC:nitrate- $\mathrm{N}$ ratios, or reactive $\mathrm{N}$ and $\mathrm{P}$ uptake to bDOC, stream site "sf" often showed a deviating behavior. Specifically, we found a release of nitrate-N at very low bulk DOC:nitrate-N ratios and a decline of SRP uptake at very high bulk DOC:SRP ratios. This behavior always occurred at stoichiometric ranges, at which one of the macronutrients clearly was limiting dissolved $\mathrm{N}$ or $\mathrm{P}$ uptake, making it unlikely that further changes in stoichiometric control by dissolved nutrients occurred. This implies other factors controlling nutrient uptake for this site. Here, we think it most likely that the particulate organic matter in the bacterial inoculum was influencing the uptake. Particulate organic $\mathrm{N}$ may have been released and remineralized to appear as nitrate- $\mathrm{N}$ at low $\mathrm{C}: \mathrm{N}$ and particulate organic $\mathrm{P}$ may have affected the SRP uptake of stream site "sf" at very high C:P. However, without detailed information of the $\mathrm{C}, \mathrm{N}$ and $\mathrm{P}$ content of the bacterial inoculum, we cannot prove or disprove this notion. Further similar experiments should make sure to also measure the particulate organic matter of the bacterial inoculum to have this information available.

We conducted our experiment in the dark in constantly shaken microcosms with stream water filtered clean of anything larger than the pores of GF/C filters. This approach removed the hydromorphological complexity of streams and the complexity of the stream food web. Such a simplified approach was needed to control the stoichiometric constraints of the system fully; however, it is unrealistic in terms of ecological scale and complexity. Furthermore, we experimented with only one, albeit natural, DOC source and only four stream waters. This experiment also did not compare responses of heterotrophic assimilatory uptake under varying DOC:nutrient ratios to those of autotrophic assimilatory uptake such as algal primary production or dissimilatory uptake such as denitrification. For denitrification, earlier research indicates a peak response at a DOC:nitrate-N molar ratio of 1 , which fits the catabolic need of denitrifiers (Taylor and Townsend 2010; Hansen et al. 2016). Hence, we propose that denitrification will not be affected by further increases in DOC:nitrate-N ratios. However, the link between DOC:nitrate- $\mathrm{N}$ and denitrification needs to be assessed in further experiments.

Moreover, in agricultural streams, autotrophic assimilation may dominate, and these systems are often assumed to be net-autotrophic during the growing season (however, see Griffiths et al. 2013). Still, there are also indications that the dominance of algae in benthic biofilms might stimulate DOC uptake either directly by priming heterotrophic assimilation with labile DOC, or indirectly by providing a better environment for heterotrophic enzymatic reactions (see Weigelhofer et al. 2020) pointing to the possibility of positive feedback between autotrophic and heterotrophic assimilation. Hence, an increase in DOC:nutrient ratios may provoke a stronger response in heterotrophic nutrient assimilation in high-light systems, such as many agricultural streams, compared to low-light systems, such as many forested streams.

Finally, we did not assess potential links between the macronutrient-access hypothesis and DOC priming. Here, DOC priming is defined as assimilation of less labile DOC induced by additions of labile DOC, resulting in greater overall DOC accessibility for bacteria. For freshwater ecosystems, DOC priming is still an active area of research, with a range of studies finding significant priming (Hotchkiss et al. 2014; 
Bianchi et al. 2015; Ward et al. 2016, 2019; Morling et al. 2017), while others propose that significant priming is unlikely (Bengtsson et al. 2014, 2018; Catalán et al. 2015). In our experiment, priming due to small additions of highly labile DOC might have increased the bioavailability of previously non-labile DOC, increasing the bioavailable DOC:reactive nutrient ratio and, hence, heterotrophic nutrient uptake. However, with our experimental design, we were unable to detect DOC priming and propose that further research assesses priming effects in the light of the macronutrient-access hypothesis.

Even when taking all the above mentioned experimental constraints into account, our experiment shows an exciting avenue of research, which may give novel insights into the controls of stream reach and fluvial network DOC and nutrient uptake. Here, we hope that the promising results of our experiment encourage further research with more source waters, more DOC sources, comparison of different uptake and remineralization pathways, and in more streamlike setups.

\section{Conclusions}

For the four investigated stream waters, we could experimentally prove a strict link between bioavailable DOC:reactive nutrient ratios and reactive nutrient uptake by heterotrophic microbial organisms (Fig. 7) previously implied for aquatic ecosystems by monitoring data, empirical in-situ assessments, and theoretical stoichiometric reasoning (Danger et al. 2008; Taylor and Townsend 2010; Wymore et al. 2016; Stutter et al. 2018). Stoichiometric approaches to nutrient uptake are not new (Sterner and Elser 2002), but the macronutrient-access hypothesis offers a different viewpoint of the topic. It combines concepts of stoichiometric homeostasis and imbalance (e.g. Sterner and Elser 2002; Danger et al. 2008; Godwin and Cotner 2015) with novel approaches linking DOC and dissolved organic nutrient molecular composition (e.g., EEM-PARAFAC) and processing to bacterial macronutrient stoichiometry. However, Helton et al. (2015) proposed that the applicability of any stoichiometric approach must be limited by thermodynamics. They argue that under highly reducing conditions, nutrient cycling is not controlled anymore by macronutrient stoichiometry but by the availability of electron donors and acceptors. Against this background, we encourage further testing of the potential and limitations of the macronutrient-access hypothesis to help develop a deeper mechanistic understanding of freshwater nutrient cycling.

The proposed stoichiometric approach may help to develop management options additionally and complementary to the source-pollution control of reactive $\mathrm{N}$ and $\mathrm{P}$ release focused on nowadays. Here, increasing $\mathrm{C}: \mathrm{N}$ and $\mathrm{C}: \mathrm{P}$ ratios should not be achieved by releasing highly reactive DOC (for example, wastewater treatment plants), but by restoring the import of natural organic carbon from the terrestrial surroundings in both dissolved and particulate form, e.g., through re-establishing floodplains and wetlands, with additional benefits for the biodiversity and functioning of those ecosystems. However, any consideration for management applications of such an approach must also assess the potential for deleterious effects of increased $\mathrm{C}: \mathrm{N}$ and $\mathrm{C}: \mathrm{P}$ ratios, namely increases in eutrophication, oxygen depletion in sediments, and the increased potential for greenhouse-gas emissions.

Independent of active management, $\mathrm{C}: \mathrm{N}$ and $\mathrm{C}: \mathrm{P}$ ratios always have changed and will continue to do so. Long-term series indicate potentially much higher DOC concentrations in the pre-agricultural past (Meyer-Jacob et al. 2015). In the future, measures to reduce reactive- $\mathrm{N}$ (Canfield et al. 2010) and reactive-P (Ockenden et al. 2017) pollution from mineral fertilizers, direct and indirect effects of lower N-atmospheric deposition (Musolff et al. 2017), as well as catchment management for climate adaptation such as wetland restoration and increased wetland-carbon storage (Erwin 2009; Kayranli et al. 2010), reforestation (Kritzberg 2017), and pyrogenic-carbon capture and storage (Blanco-Canqui 2019) will likely again shift aquatic ecosystems towards higher DOC concentrations and higher DOC:reactive N or DOC:reactive $\mathrm{P}$ ratios. Here, we need to deepen our understanding of the potential impacts of those scenarios on nutrient cycling across wide ranges of environmental conditions and river network scales. This study is one starting point, which needs to be followed by more extensive research on the links between macronutrient stoichiometry, ecosystem functioning, ecosystem services, and the approach's scaling properties. 
Acknowledgements We thank Yvonne Rosenlöcher for preparing the DOC leaf leachate and her support of the DOC treatment preparation, and the team of the Water Analytics laboratory at UFZ Magdeburg for their analysis of the many hundred samples. Here, we especially thank Andrea Hoff for the support in the sample container and filter preparation, sample organization and nutrient-concentration measurements, and Ina Siebert for determining DOC concentrations. M. Stutter received funding from the Scottish Government's Rural and Environment Sciences and Analytical Service's Environment Program and A. Wachholz is funded by the Helmholtz International Research School TRACER, grand no. HIRS0017. We thank the associate editor, Prof. J. M. Melack, and the two anonymous reviewers for their many helpful comments, which significantly improved the clarity of the manuscript.

Author contributions All authors contributed to the development, writing, and commenting of the manuscript. YT mainly conducted the experiments, DG, WT \& JT supervised and supported the experiments. DG led the data analysis and statistics, AW significantly contributed to the statistics, all authors contributed to the data analysis.

Funding Open Access funding enabled and organized by Projekt DEAL. M. Stutter received funding from the Scottish Government's Rural and Environment Sciences and Analytical Service's Environment Program. A. Wachholz is funded by the Helmholtz International Research School TRACER, Grand No. HIRS-0017.

Data availability The data are available from the corresponding author upon request.Code availability: The $\mathrm{R}$ codes for EEM-PARAFAC, data analyses, and statistics are available from the corresponding author upon request.

\section{Declarations}

Conflict of interest There are no conflicts of interest.

Open Access This article is licensed under a Creative Commons Attribution 4.0 International License, which permits use, sharing, adaptation, distribution and reproduction in any medium or format, as long as you give appropriate credit to the original author(s) and the source, provide a link to the Creative Commons licence, and indicate if changes were made. The images or other third party material in this article are included in the article's Creative Commons licence, unless indicated otherwise in a credit line to the material. If material is not included in the article's Creative Commons licence and your intended use is not permitted by statutory regulation or exceeds the permitted use, you will need to obtain permission directly from the copyright holder. To view a copy of this licence, visit http://creativecommons.org/licenses/by/4.0/.

\section{References}

Asmala E, Autio R, Kaartokallio H et al (2014) Processing of humic-rich riverine dissolved organic matter by estuarine bacteria: effects of predegradation and inorganic nutrients. Aquat Sci 76:451-463. https://doi.org/10.1007/s00027014-0346-7

Attermeyer K, Tittel J, Allgaier M et al (2015) Effects of light and autochthonous carbon additions on microbial turnover of allochthonous organic carbon and community composition. Microb Ecol 69:361-371. https://doi.org/10.1007/ s00248-014-0549-4

Bahram M, Bro R, Stedmon C, Afkhami A (2006) Handling of Rayleigh and Raman scatter for PARAFAC modeling of fluorescence data using interpolation. $\mathrm{J}$ Chemom 20:99-105

Bengtsson MM, Wagner K, Burns NR et al (2014) No evidence of aquatic priming effects in hyporheic zone microcosms. Sci Rep 4:5187. https://doi.org/10.1038/srep05187

Bengtsson MM, Attermeyer K, Catalán N (2018) Interactive effects on organic matter processing from soils to the ocean: are priming effects relevant in aquatic ecosystems? Hydrobiologia. https://doi.org/10.1007/s10750-018-36722

Bianchi TS, Thornton DCO, Yvon-Lewis SA et al (2015) Positive priming of terrestrially derived dissolved organic matter in a freshwater microcosm system. Geophys Res Lett 42:5460-5467. https://doi.org/10.1002/ 2015GL064765

Blanco-Canqui H (2019) Biochar and water quality. J Environ Qual 48:2-15. https://doi.org/10.2134/jeq2018.06.0248

Canfield DE, Glazer AN, Falkowski PG (2010) The evolution and future of earth's nitrogen cycle. Science 330:192-196. https://doi.org/10.1126/science.1186120

Catalán N, Kellerman AM, Peter H et al (2015) Absence of a priming effect on dissolved organic carbon degradation in lake water. Limnol Oceanogr 60:159-168. https://doi.org/ 10.1002/lno.10016

Conley DJ, Paerl HW, Howarth RW et al (2009) Controlling eutrophication: nitrogen and phosphorus. Science 323:1014-1015. https://doi.org/10.1126/science.1167755

Danger M, Daufresne T, Lucas F et al (2008) Does Liebig's law of the minimum scale up from species to communities? Oikos 117:1741-1751. https://doi.org/10.1111/j.16000706.2008.16793.x

del Giorgio PA, Cole JJ (1998) Bacterial growth efficiency in natural aquatic systems. Annu Rev Ecol Syst 29:503-541. https://doi.org/10.1146/annurev.ecolsys.29.1.503

Erwin KL (2009) Wetlands and global climate change: the role of wetland restoration in a changing world. Wetl Ecol Manag 17:71-84. https://doi.org/10.1007/s11273-0089119-1

Fellman JB, Hood E, Edwards RT, Jones JB (2009) Uptake of allochthonous dissolved organic matter from soil and 
salmon in coastal temperate rainforest streams. Ecosystems 12:747-759

Fellman JB, Hood E, Spencer RGM (2010) Fluorescence spectroscopy opens new windows into dissolved organic matter dynamics in freshwater ecosystems: a review. Limnol Oceanogr 55:2452-2462. https://doi.org/10.4319/ lo.2010.55.6.2452

Fellman JB, Petrone KC, Grierson PF (2011) Source, biogeochemical cycling, and fluorescence characteristics of dissolved organic matter in an agro-urban estuary. Limnol Oceanogr 56:243-256. https://doi.org/10.4319/lo.2011.56. 1.0243

Fiedler D, Graeber D, Badrian M, Köhler J (2015) Growth response of four freshwater algal species to dissolved organic nitrogen of different concentration and complexity. Freshw Biol 60:1613-1621. https://doi.org/10.1111/fwb. 12593

Godwin CM, Cotner JB (2015) Aquatic heterotrophic bacteria have highly flexible phosphorus content and biomass stoichiometry. ISME J 9:2324-2327. https://doi.org/10.1038/ ismej. 2015.34

Godwin CM, Cotner JB (2018) What intrinsic and extrinsic factors explain the stoichiometric diversity of aquatic heterotrophic bacteria? ISME J 12:598-609. https://doi. org/10.1038/ismej.2017.195

Graeber D, Gücker B, Zwirnmann E et al (2012) Dialysis is superior to anion exchange for removal of dissolved inorganic nitrogen from freshwater samples prior to dissolved organic nitrogen determination. Environ Chem 9:529-536. https://doi.org/10.1071/EN11170

Graeber D, Gelbrecht J, Kronvang B et al (2012) Technical Note: Comparison between a direct and the standard, indirect method for dissolved organic nitrogen determination in freshwater environments with high dissolved inorganic nitrogen concentrations. Biogeosciences 9:4873-4884. https://doi.org/10.5194/bg-9-4873-2012

Graeber D, Poulsen JR, Heinz M et al (2018) Going with the flow: Planktonic processing of dissolved organic carbon in streams. Sci Total Environ 625:519-530. https://doi.org/ 10.1016/j.scitotenv.2017.12.285

Griffiths NA, Tank JL, Royer TV et al (2013) Agricultural land use alters the seasonality and magnitude of stream metabolism. Limnol Oceanogr 58:1513-1529. https://doi.org/ 10.4319/lo.2013.58.4.1513

Hansen AT, Dolph CL, Finlay JC (2016) Do wetlands enhance downstream denitrification in agricultural landscapes? Ecosphere 7:e01516. https://doi.org/10.1002/ecs2.1516

Helton AM, Ardón M, Bernhardt ES (2015) Thermodynamic constraints on the utility of ecological stoichiometry for explaining global biogeochemical patterns. Ecol Lett 18:1049-1056. https://doi.org/10.1111/ele.12487

Hotchkiss ER, Hall RO, Baker MA et al (2014) Modeling priming effects on microbial consumption of dissolved organic carbon in rivers. J Geophys Res Biogeosci 119:982-995. https://doi.org/10.1002/2013JG002599

Jarvie HP, Smith DR, Norton LR et al (2018) Phosphorus and nitrogen limitation and impairment of headwater streams relative to rivers in Great Britain: a national perspective on eutrophication. Sci Total Environ 621:849-862. https:// doi.org/10.1016/j.scitotenv.2017.11.128

Johnson LT, Royer TV, Edgerton JM, Leff LG (2012) Manipulation of the dissolved organic carbon pool in an agricultural stream: responses in microbial community structure, denitrification, and assimilatory nitrogen uptake. Ecosystems 15:1027-1038. https://doi.org/10.1007/ s10021-012-9563-x

Kamjunke N, Lechtenfeld OJ, Herzsprung P (2020) Quality of dissolved organic matter driven by autotrophic and heterotrophic microbial processes in a large River. Water 12:1577. https://doi.org/10.3390/w12061577

Kaushal SS, Lewis WM (2005) Fate and transport of organic nitrogen in minimally disturbed montane streams of Colorado, USA. Biogeochemistry 74:303-321

Kayranli B, Scholz M, Mustafa A, Hedmark Å (2010) Carbon storage and fluxes within freshwater wetlands: a critical review. Wetlands 30:111-124. https://doi.org/10.1007/ s13157-009-0003-4

Kothawala DN, von Wachenfeldt E, Koehler B, Tranvik LJ (2012) Selective loss and preservation of lake water dissolved organic matter fluorescence during long-term dark incubations. Sci Total Environ 433:238-246. https://doi. org/10.1016/j.scitotenv.2012.06.029

Kothawala DN, Murphy KR, Stedmon CA et al (2013) Inner filter correction of dissolved organic matter fluorescence. Limnol Oceanogr-Methods 11:616-630. https://doi.org/ 10.4319/lom.2013.11.616

Kritzberg ES (2017) Centennial-long trends of lake browning show major effect of afforestation. Limnol Oceanogr Lett 2:105-112. https://doi.org/10.1002/lol2.10041

Kronvang B, Jeppesen E, Conley DJ et al (2005) Nutrient pressures and ecological responses to nutrient loading reductions in Danish streams, lakes and coastal waters. J Hydrol 304:274-288. https://doi.org/10.1016/j.jhydrol. 2004.07.035

Lawaetz AJ, Stedmon CA (2009) Fluorescence intensity calibration using the Raman scatter peak of water. Appl Spectrosc 63:936-940

Lee WT, Westerhoff P (2005) Dissolved organic nitrogen measurement using dialysis pretreatment. Environ Sci Technol 39:879-884. https://doi.org/10.1021/es048818y

Makino W, Cotner JB (2004) Elemental stoichiometry of a heterotrophic bacterial community in a freshwater lake: implications for growth- and resource-dependent variations. Aquat Microb Ecol 34:33-41. https://doi.org/10. 3354/ame034033

Meyer-Jacob C, Tolu J, Bigler C et al (2015) Early land use and centennial scale changes in lake-water organic carbon prior to contemporary monitoring. Proc Natl Acad Sci 112:6579-6584. https://doi.org/10.1073/pnas.1501505112

Morling K, Raeke J, Kamjunke N et al (2017) Tracing aquatic priming effect during microbial decomposition of terrestrial dissolved organic carbon in chemostat experiments. Microb Ecol 74:534-549. https://doi.org/10.1007/s00248017-0976-0

Murphy KR, Stedmon CA, Graeber D, Bro R (2013) Fluorescence spectroscopy and multi-way techniques: PARAFAC. 
Anal Methods 5:6557-6566. https://doi.org/10.1039/ C3AY41160E

Murphy KR, Stedmon CA, Wenig P, Bro R (2014) OpenFluoran online spectral library of auto-fluorescence by organic compounds in the environment. Anal Methods 6:658-661. https://doi.org/10.1039/C3AY41935E

Musolff A, Selle B, Büttner O et al (2017) Unexpected release of phosphate and organic carbon to streams linked to declining nitrogen depositions. Glob Change Biol 23:1891-1901. https://doi.org/10.1111/gcb.13498

Nimptsch J, Woelfl S, Osorio S et al (2015) Tracing dissolved organic matter (DOM) from land-based aquaculture systems in North Patagonian streams. Sci Total Environ 537:129-138. https://doi.org/10.1016/j.scitotenv.2015.07. 160

Ockenden MC, Hollaway MJ, Beven KJ et al (2017) Major agricultural changes required to mitigate phosphorus losses under climate change. Nat Commun 8:161. https://doi.org/ 10.1038/s41467-017-00232-0

Petrone KC, Fellman JB, Hood E et al (2011) The origin and function of dissolved organic matter in agro-urban coastal streams. J Geophys Res 116:1-13. https://doi.org/10.1029/ 2010JG001537

Pucher M, Wünsch U, Weigelhofer G et al (2019) staRdom: versatile software for analyzing spectroscopic data of dissolved organic matter in R. Water 11:2366. https://doi.org/ $10.3390 /$ w 11112366

R Core Team (2020) R: a language and environment for statistical computing. R Foundation for Statistical Computing, Vienna

Rodríguez-Cardona B, Wymore AS, McDowell WH (2016) DOC:NO3 - ratios and NO3- uptake in forested headwater streams. J Geophys Res Biogeosci 121:2015JG003146. https://doi.org/10.1002/ 2015JG003146

Scott T, Cotner J, LaPara T (2012) Variable stoichiometry and homeostatic regulation of bacterial biomass elemental composition. Front Microbiol 3:42. https://doi.org/10. 3389/fmicb.2012.00042

Siemens J, Kaupenjohann M (2002) Contribution of dissolved organic nitrogen to $\mathrm{N}$ leaching from four German agricultural soils. J Plant Nutr Soil Sci 165:675-681. https:// doi.org/10.1002/jpln.200290002

Smith DR, Jarvie HP, Bowes MJ (2017) Carbon, nitrogen, and phosphorus stoichiometry and eutrophication in river Thames Tributaries UK. Agric Environ Lett. https://doi. org/10.2134/ael2017.06.0020

Soares ARA, Bergström A-K, Sponseller RA et al (2017) New insights on resource stoichiometry: assessing availability of carbon, nitrogen, and phosphorus to bacterioplankton. Biogeosciences 14:1527-1539. https://doi.org/10.5194/ bg-14-1527-2017

Sterner RW, Elser JJ (2002) Ecological stoichiometry: the biology of elements from molecules to biosphere. Princeton University Press, Princeton

Stutter MI, Graeber D, Evans CD et al (2018) Balancing macronutrient stoichiometry to alleviate eutrophication. Sci Total Environ 634:439-447. https://doi.org/10.1016/j. scitotenv.2018.03.298
Stutter M, Graeber D, Weigelhofer G (2020) Available dissolved organic carbon alters uptake and recycling of phosphorus and nitrogen from river sediments. Water 12:3321. https://doi.org/10.3390/w12123321

Stutter M, Wyness A, Watson H, Dodd N (2020) Coupled macronutrient cycling in stream biofilms: Effects of stoichiometry, light and temperature. Sci Total Environ 703:134880. https://doi.org/10.1016/j.scitotenv.2019. 134880

Taylor PG, Townsend AR (2010) Stoichiometric control of organic carbon-nitrate relationships from soils to the sea. Nature 464:1178-1181. https://doi.org/10.1038/ nature 08985

Tezuka Y (1990) Bacterial regeneration of ammonium and phosphate as affected by the carbon:nitrogen:phosphorus ratio of organic substrates. Microb Ecol 19:227-238. https://doi.org/10.1007/BF02017167

Vrede K, Heldal M, Norland S, Bratbak G (2002) Elemental composition $(\mathrm{C}, \mathrm{N}, \mathrm{P})$ and cell volume of exponentially growing and nutrient-limited bacterioplankton. Appl Environ Microbiol 68:2965-2971. https://doi.org/10.1128/ AEM.68.6.2965-2971.2002

Ward ND, Bianchi TS, Sawakuchi HO et al (2016) The reactivity of plant-derived organic matter and the potential importance of priming effects along the lower Amazon River. J Geophys Res Biogeosci 121:1522-1539. https:// doi.org/10.1002/2016JG003342

Ward ND, Sawakuchi HO, Richey JE et al (2019) Enhanced aquatic respiration associated with mixing of clearwater tributary and turbid Amazon River waters. Front Earth Sci. https://doi.org/10.3389/feart.2019.00101

Weigelhofer G (2017) The potential of agricultural headwater streams to retain soluble reactive phosphorus. Hydrobiologia 793:149-160. https://doi.org/10.1007/s10750-0162789-4

Weigelhofer G, Welti N, Hein T (2013) Limitations of stream restoration for nitrogen retention in agricultural headwater streams. Ecol Eng 60:224-234. https://doi.org/10.1016/j. ecoleng.2013.07.057

Weigelhofer G, Jirón TS, Yeh T-C et al (2020) Dissolved organic matter quality and biofilm composition affect microbial organic matter uptake in stream flumes. Water 12:3246. https://doi.org/10.3390/w12113246

Wheeler KI, Levia DF, Hudson JE (2017) Tracking senescenceinduced patterns in leaf litter leachate using parallel factor analysis (PARAFAC) modeling and self-organizing maps. J Geophys Res Biogeosci 122:2233-2250. https://doi.org/ 10.1002/2016JG003677

Williams CJ, Yamashita Y, Wilson HF et al (2010) Unraveling the role of land use and microbial activity in shaping dissolved organic matter characteristics in stream ecosystems. Limnol Oceanogr 55:1159-1171. https://doi.org/10.4319/ lo.2010.55.3.1159

Wollschläger U, Attinger S, Borchardt D et al (2017) The Bode hydrological observatory: a platform for integrated, interdisciplinary hydro-ecological research within the TERENO Harz/Central German Lowland Observatory. Environ Earth Sci 76:29. https://doi.org/10.1007/s12665-016-63275 
Wymore AS, Coble AA, Rodríguez-Cardona B, McDowell WH (2016) Nitrate uptake across biomes and the influence of elemental stoichiometry: a new look at LINX II. Glob Biogeochem Cycles. https://doi.org/10.1002/ 2016GB005468

Yoro SC, Panagiotopoulos C, Sempéré R (1999) Dissolved organic carbon contamination induced by filters and storage bottles. Water Res 33:1956-1959. https://doi.org/ 10.1016/S0043-1354(98)00407-2

Publisher's Note Springer Nature remains neutral with regard to jurisdictional claims in published maps and institutional affiliations. 